\title{
Early Neolithic population dynamics in the Eastern Balkans and the Great Hungarian Plain
}

\author{
Tamara Blagojević ${ }^{1}$, Marko Porčić ${ }^{1,2}$, Kristina Penezić ${ }^{1}$ and Sofija Stefanović ${ }^{1,2}$ \\ 1 Bioarchaeology Group, Institute Biosense - the Research and Development Institute for Information Technologies \\ in Biosystems, University of Novi Sad, Novi Sad, RS \\ tamara.blagojevic@biosense.rs \\ 2 Laboratory for bioarchaeology, Department of Archaeology, Faculty of Philosophy, \\ University of Beograd, Beograd, RS
}

\begin{abstract}
In this study, we reconstruct population dynamics in the Early Neolithic of the Eastern Balkans and the Great Hungarian Plain using frequency of radiocarbon dates as a population proxy. The method of summed calibrated radiocarbon probability distributions is applied to a set of dates recently published in Bulgaria and Hungary. The aim is to test the hypothesis of the Neolithic demographic transition (NDT) in these regions and to compare the patterns between these two and neighbouring regions. The results show that episodes of population growth occurred in both regions, which is in partial agreement with the predictions of the NDT theory. Population growth is detected, but it is followed by a bust, rather than stabilisation as predicted for the second phase of the NDT.
\end{abstract}

KEY WORDS - Early Neolithic; Neolithic demographic transition; palaeodemography; radiocarbon; Southeast Europe

\section{Zgodnje neolitske dinamike poselitve na Vzhodnem Balkanu in v Veliki madžarski nižini}

\begin{abstract}
IZVLEČEK - V članku poskušamo rekonstruirati populacijske dinamike v času zgodnjega neolitika na območju vzhodnega Balkana in Velike madžarske nižine, in sicer z uporabo pogostnosti radiokarbonskih datumov kot kazalcev poselitve. Metodo vsote verjetnostne razporeditve kalibriranih radiokarbonskih datumov smo uporabili pri analizi datumov, ki so bili nedavno objavljeni v Bolgariji in na Madžarskem. Na teh območjih smo preverjali hipotezo t.i. neolitske demografske tranzicije (NDT) in primerjali dobljene vzorce s tistimi v sosednjih regijah. Rezultati kažejo, da so se epizode rasti poselitve zgodile $v$ obeh regijah, kar je delno $v$ skladu z napovedmi teorije NDT. Zaznali smo sicer rast poselitve, ki pa ji sledi nenaden padec, kar ni v skladu z napovedmi za drugo fazo NDT, ki predvideva stabilizacijo.
\end{abstract}

KLJUČNE BESEDE - zgodnji neolitik; neolitska demografska tranzicija; paleodemografija; radiokarbonsko datiranje; jugovzhodna Evropa

\section{Introduction}

It is commonly accepted that the Neolithic was introduced to Europe from the Near East, and new genetic and bioarchaeological evidence undoubtedly show that these processes included movements of people (Davison et al. 2007; Haak et al. 2010; Brami, Heyd 2011; Fort 2012; Pinhasi et al. 2012; Boric, Price
2013; Gurova, Bonsall 2014; Özdoğan 2014; Mathieson et al. 2015; Szécsényi-Nagy et al. 2015; Hofmanová et al. 2016). The directions and rates of spread of the Neolithic in different regions of Europe have been important issues in numerous studies, many of which offered possible models of pop- 
ulation expansion. Different models have been suggested for the process, the most frequently considered being: the wave-of-advance model, leap-frog colonisation, and diffusion of cultural novelties (cultural transmission) (Ammerman, Cavalli-Sforza 1971, 1973; Tringham 2000; Whittle et al. 2002; Bar-Yosef 2004; Pinhasi et al. 2005; Davison et al. 2007; Bocquet-Appel et al. 2009; Borić, Price 2013). In recent years, the process of neolithisation has been studied as a more complex combination of demic and cultural diffusion (Wirtz, Lemmen 2003; Fort 2012; 2015).

The Neolithic way of life brought changes in subsistence and mobility patterns, and a major shift in population structure and dynamics known as the Neolithic Demographic Transition (NDT). According to Jean-Pierre Bocquet-Appel (2002; 2008; 2011a; 2011b; 2013; Bocquet-Appel, Bar-Yosef 2008a), the NDT was a two-stage process - the first stage being characterised by exponential population growth caused by increased fertility, followed by a second stage marked by increased mortality and decelerating growth. It is assumed that the increase in fertility was caused by changes in lifestyle which accompanied the Neolithic - dietary (introduction of new, more nutritious food), and changes in residential mobility (sedentary lifestyle). The increase in mortality that followed, especially among infants, was a result of numerous factors - introduction of new pathogens, lack of drinking water, contamination by feces, reduced breastfeeding and higher workload (Bocquet-Appel 2008.49; 2013.2). When the mortality rate equaled the birth rate, population growth stopped.

The pattern of Neolithic population dynamics, based on the frequency of radiocarbon dates from Western, Northern and Central Europe, consists of a population boom that occurred at the beginning of the period, followed by a population bust after a few centuries (Shennan et al. 2013; Timpson et al. 2014). This pattern is in agreement with predictions of the NDT theory regarding its first phase, when population growth should occur. A recent study has shown that a similar pattern is observed in the Early Neolithic of the Central Balkans (Porčić et al. 2016).

In this paper, we extend the paleodemographic research to the area of Eastern Balkans and the Great Hungarian Plain. The aim is to reconstruct population dynamics and to test the NDT hypothesis on two datasets from Southeast Europe, where such studies have been lacking.
Two routes of expansion of the Neolithic way of life into Europe have been proposed. The continental route led from Thessaly, where Neolithic was introduced around the middle of the $7^{\text {th }}$ millennium cal BC (Perlès et al. 2013) through the Balkans, and to Central, Western and Eastern Europe (Bocquet-Appel et al. 2009; Brami, Heyd 2011; Özdoğan 2014). The maritime (Mediterranean) route led from the coast of the Ionian Sea, along the eastern and western Adriatic coast, and further to the western Mediterranean and Iberia. Recent studies (Wirtz, Lemmen 2003; Bocquet-Appel et al. 2009; Lemmen et al. 2011; Silva, Steele 2014; Weninger et al. 2014; Brami, Zanotti 2015) emphasised the complexity of these processes, and different rates and timings for different European regions. These differences depended on various factors, such as geography, climate and sociocultural trends.

The present state of research suggests that the Neolithic spread to the territory of Eastern Balkans (mostly modern-day Bulgaria), along the valleys of the Vardar, Struma and Marica rivers (Boyadzhiev 2009). After settling in Southwestern Bulgaria and Thrace, Early Neolithic populations spread further north. The Neolithisation of this territory was gradual, in a south to north direction, and absolute dates from sites such as Poljanica-Platoto and Džuljunica-Smărdeš date the beginning of these processes to around 6200/6100 cal BC (Boyadzhiev 2009.11; Krauß et al. 2014.63, Tab. 1). The Early Neolithic lasted until around $5400 / 5350 \mathrm{cal} \mathrm{BC}$, with the transition to the Late Neolithic occurring between 5500/5450 and $5400 / 5350$ cal BC, which is thought to have been a gradual and smooth process (Gatsov, Boyadzhiev 2009.26).

The Early Neolithic on the Great Hungarian Plain (modern-day Hungary) is represented by the Starčevo and Körös cultures. The settling of these early farming populations was concentrated in the valleys of several rivers: Tisza, Körös, Maros and Beretyó. The highest density of sites has been found on the southern part of the Great Hungarian Plain, which is explained as a result of its rich and diverse landscape (Paluch 2012.49). The earliest ${ }^{14} \mathrm{C}$ dates from the southernmost sites, such as Deszk-1, Pitvaros, Maroslele-Pana and Olajkút, indicate that the beginning of Körös culture can be dated to around $6000 / 5910$ cal BC. A south-to-north expansion is also suggested, with the earliest dates for the northernmost (Upper Tisza) region covering the time span between 5630 and 5470 cal BC (Domboróczki 2010; Domboróczki, Raczky 2010; Oross, Siklósi 2012). 


\section{Data and method}

In this study, published data from Hungary (Anders, Siklósi 2012) and Bulgaria (Gatsov, Boyadzhiev 2009; Krau $\beta$ et al. 2014) were used. A total of 179 published radiocarbon dates from 16 Bulgarian sites and 117 dates from 24 sites from the territory of Hungary were analysed (Fig. 1; Appendix 1). Dates with large standard errors (170 radiocarbon years and greater) and dates that were out of the currently accepted chronological range for the Early Neolithic in Southeast Europe ( 6200-5300 cal BC) were excluded from the analysis. 1

The population dynamics were reconstructed by applying the summed calibrated radiocarbon probability distributions (SCPD) method. The main assumption of this method is that the quantity of material culture is directly proportional to population size in a certain time interval in a given region (Rick 1987; Shennan et al. 2013; Williams 2012). If the number of radiocarbon dates is large enough, then the frequency of dates from a specific time period will be directly proportional to the quantity of archaeological remains from that period, and hence to the size of the population that produced them. The method that was applied in this study was developed by Stephen Shennan et al. (2013) and Adrian Timpson et al. (2014), and it accounts for biases that can greatly affect the final result: the effects of the calibration curve, research bias and effects of taphonomy. The analysis was performed in $\mathrm{R}$ programming language ( $R$ Core Team 2014), using the Bchron package for calibrating dates (Parnell 2014), and the INTCAL 13 calibration curve (Reimer et al. 2013).

The research bias is the result of different sampling strategies, depending on particular research questions. In other words, samples are usually not collected randomly, but in order to provide chronological information for specific archaeological contexts. In order to reduce the research bias, a binning procedure was performed at the beginning of the analysis. Radiocarbon dates were binned into site-phases, and sorted in decreasing order within each sitephase. Subdivision into bins within site-phases was performed if the difference between two adjacent dates was greater than 200 radiocarbon years. After the calibration, dates were summed within and between bins, and normalised to produce the final
SCPD curve. This procedure controls for research bias due to the different number of dates from different sites and site phases, but it cannot control for the bias resulting from the selection of sites and site phases themselves. The binning procedure performed on the 179 Early Neolithic dates from Bulgaria produced 22 bins, while the same procedure performed on 117 Early Neolithic dates from Hungary produced 26.

Taphonomic bias refers to the loss of archaeological material over time due to various taphonomic factors. In order to address this source of bias, the taphonomic exponential curve equation developed by Todd A. Surovell et al. (2009) was used as a null model. The null model assumes that the population was stationary and that, apart from the shape of the calibration curve, the taphonomy is the only factor which affects the shape of the empirical SCPD curve. According to the probabilities given by the null model, calendar dates from the specified time interval were randomly sampled, which produced a large number of simulated radiocarbon datasets. The number of dates for each simulated dataset is equal to the number of bins in the empirical data set. This procedure was repeated many times; for the Early Neolithic dates from Hungary and Bulgaria, we simulated 10000 null model SCPDs. Sampled calendar dates were then 'back calibrated' and recalibrated afterwards, and summed to produce the simulated SCPD pattern. Finally, the empirical SCPD curve was compared to the 95\% confidence intervals calculated from the simulated SCPD values. When the empirical SCPD is above or below the $95 \%$ confidence intervals, there is a statistically significant growth or decline of population relative to the null model. This whole procedure was undertaken in order to assess the statistical significance of the empirical SCPD pattern.

\section{Results}

The results of the SCPD method for the territory of Bulgaria are shown in Figure 2. After $\sim 6000 \mathrm{cal} \mathrm{BC}$, the curve begins to increase, reaching a peak around $5700 \mathrm{cal} \mathrm{BC}$, after which it decreases. However, none of the changes in the curve reach the threshold of statistical significance, as the curve is always within the $95 \% \mathrm{CI}$ limits, meaning that it is consistent with the null model, which assumes uniform population (with effects of taphonomy).

1 The omitted dates are from the following Bulgarian sites: Ovčarovo-gorata (Bln-2031), Galabnik (GrN-19786), Poljanica-platoto (Bln-1571) and Džuljunica-Smărdeš (OxA-24937). From Hungarian sites, the dates that were excluded are: Ecsegfalva 23 (OxA12857), Endrôd 6 (Deb-408, Deb-450), Maroslele-Pana (0xA-9403, Deb-2733), Szajol-Felsóföld (Deb-473, Deb-474), Szakmár-Kisülés (Deb-413), Szarvas 23 (BM-1865R) and Szarvas 56 (Deb-396). 
The results of the SCPD method for the territory of Hungary are shown in Figure 3. The empirical curve increases after $\sim 6200 \mathrm{cal} \mathrm{BC}$ and goes beyond the upper $95 \% \mathrm{CI}$ limit between $\sim 5750$ and $\sim 5500 \mathrm{cal}$ $\mathrm{BC}$, meaning that in this interval, there was a significant increase relative to the null model, which assumes uniform population (with effects of taphonomy). After this interval, the curve abruptly drops, but stays within the 95\% CI limits. Around $5200 \mathrm{cal}$
$\mathrm{BC}$, a minor, but statistically significant drop can be observed.

\section{Discussion}

In the Eastern Balkans, the curve started to increase with the beginning of the Neolithic. The peak around 5700 cal BC occurred afterwards, and may be considered as indicative of the NDT. The lack of statistical

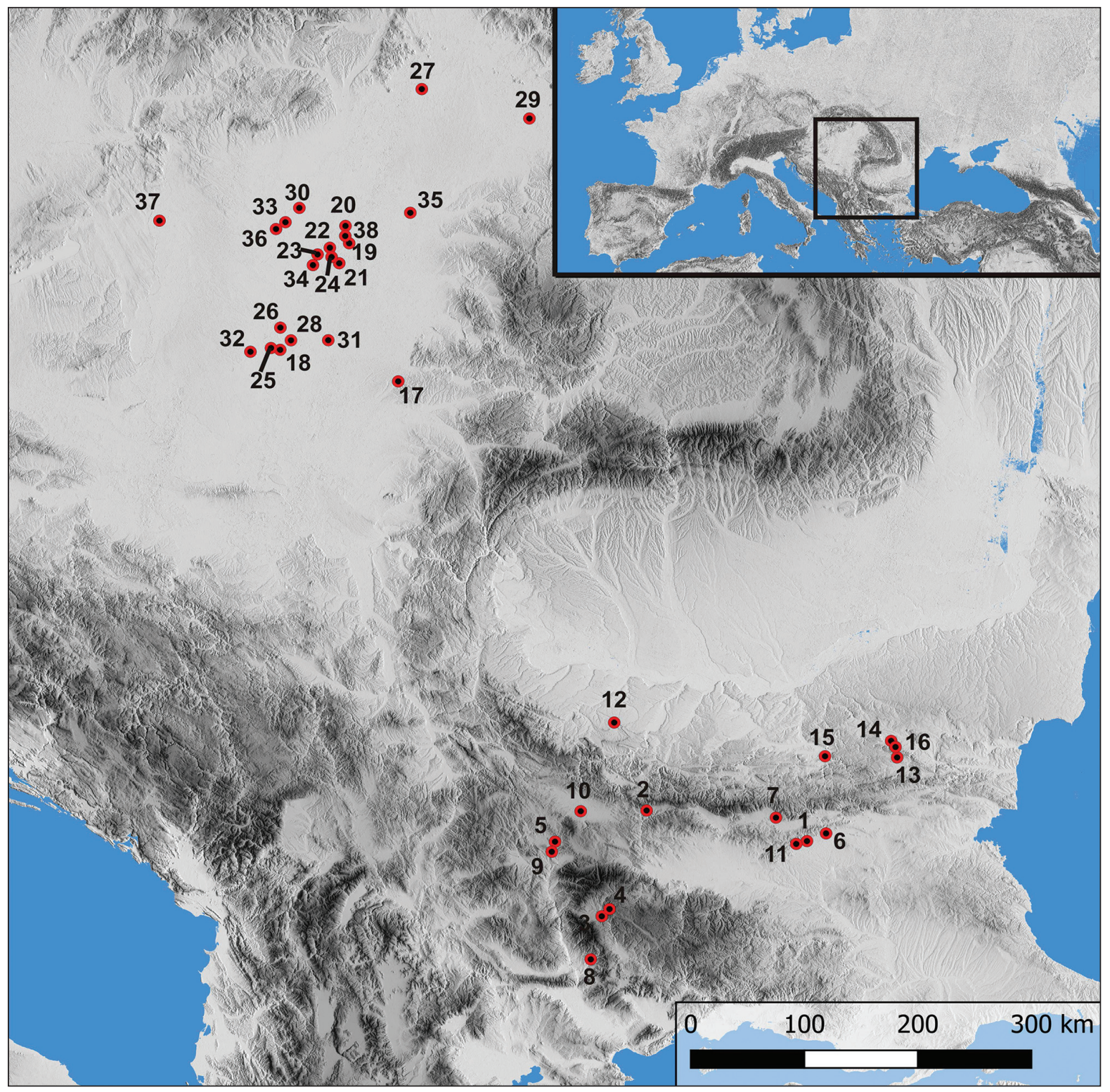

Fig. 1. Early Neolithic sites from Bulgaria (1-16) and Hungary (17-38) with radiocarbon dates included in this study: 1 Azmak, 2 Čavdar, 3 Dobrinište, 4 Elešnica, 5 Galabnik, 6 Karanovo, 7 Kazanlak, 8 Kovačevo, 9 Kremenik (Sapareva Banja), 10 Slatina, 11 Stara Zagora (Okražna bolnica), 12 Ohoden, 13 Ovčarovo-gorata, 14 Poljanica-platoto, 15 Džuljunica-Smărdeš; 16 Ovcharovo-platoto 2; 17 Battonya-Basarága, 18 Deszk-Olajkút, 19 Dévaványa-Katalszeg, 20 Ecsegfalva 23, 21 Endród 35, 22 Endröd 39, 23 Endród 119, 24 Endród-Varnyai-tanya, 25 Gyálarét-Szilágyi major, 26 Hódmezóvásárhely-KotacpartVata-tanya, 27 Ibrány-Nagyerdó, 28 Maroslele-Pana, 29 Méhtelek-Nádas, 30 Nagykörü-TszGyümölcsös, 31 Pitvaros-Viztározó, 32 Röszke-Lúdvár, 33 Szajol-Felsóföld, 34 Szarvas 23; 35 Szentpéterszeg-Körtvélyes, 36 Szolnok-Szanda, 37 Tiszaszólós-Domaháza-puszta; 38 Dévaványa-Réhelyi gát (map produced by Jugoslav Pendić and Kristina Penezić). 
significance (at the 0.05 level) of the deviation from the null model is most probably due to the low effective sample size (the number of bins is only 22), which implies low statistical power.

The results for the Hungarian Plain dates show a significant peak around $\sim 5750$ cal BC, which can be interpreted as population growth at the beginning of the Neolithic, and the signal of the NDT. It is followed by a sharp decrease in the curve at $\sim 5500$ cal $\mathrm{BC}$, suggesting a population bust in this period.

The observed pattern - a population increase at the beginning of the Neolithic, followed by a population decrease after about 150 years for Bulgaria, and about 250 years for Hungary - correspond to the boom and bust pattern observed in other regions in Europe and the Balkans (Shennan, Edinborough 2007; Shennan et al. 2013; Timpson et al. 2014; Porčić et al. 2016; Pilaar Birch, Vander Linden 2017).

When compared to the results obtained for the territory of Serbia (Porčić et al. 2016), it can be seen that they are quite similar in general, but some regional differences should be further discussed (Fig. 4). In Porčić et al. (2010) it was shown that the SCPD curve for data from Serbia had two statistically significant peaks ( $\sim 6000 \mathrm{cal} \mathrm{BC}$ and $\sim 5650$ cal BC) and a major drop between. Two explanations have been proposed. The first perceives these changes as real demographic patterns that reflect major population growth followed by increased mortality or migration, with a rebound occurring after 350 years. The other explanation would be that this result is a consequence of a research bias that led to oversampling the earliest Early Neolithic contexts and that the peak around $\sim 5650$ cal BC is most probably the signal of the NDT (Porčić et al. 2016.6-7). In a recent study by Suzanne Pilaar Birch and Marc Vander Linden (2017), which primarily deals with the correlation between environmental changes and population dynamics dur-

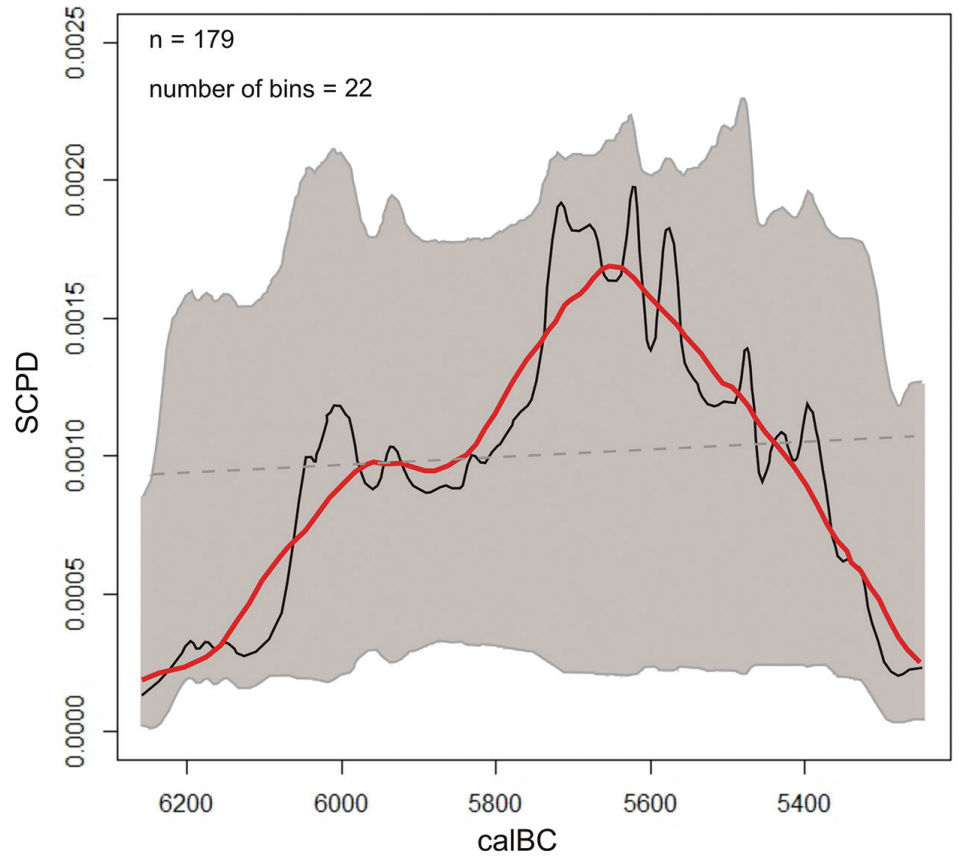

Fig. 2. Results of the SCPD analysis based on the Early Neolithic radiocarbon dates from Bulgaria. SCPD empirical curve (black line) for Early Neolithic dates, with 95\% confidence intervals (shaded) based on 10000 simulations from the null model (grey dashed line) and 200 year rolling mean (red line); number of dates = 179; number of bins $=22$; global $p$ value $=$ 0.5516 .

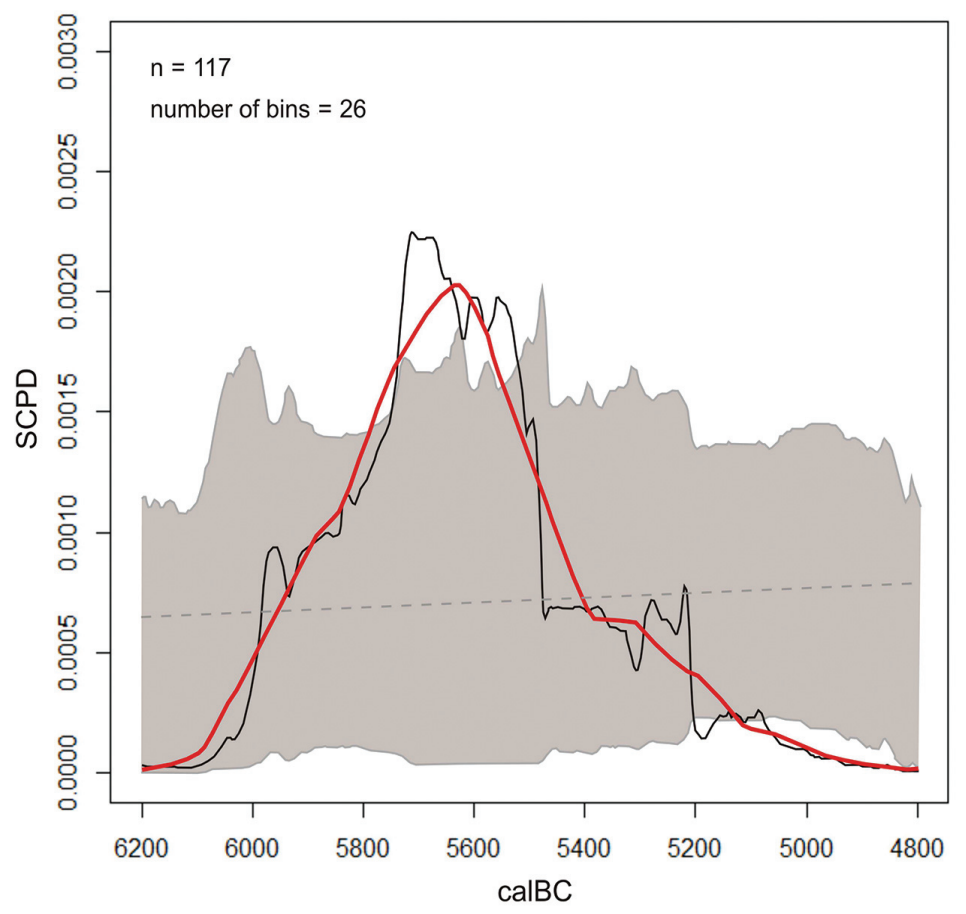

Fig. 3. Results of the SCPD analysis based on the Early Neolithic radiocarbon dates from Hungary. SCPD empirical curve (black line) for Early Neolithic dates, with 95\% confidence intervals (shaded) based on 10000 simulations from the null model (grey dashed line) and 200 year rolling mean (red line); number of dates $=117$; number of bins $=26$; global $p$ value $=$ 0.0037 . 
ing the Late Pleistocene and Early Holocene in the eastern Adriatic and western Balkans, the SCPD method was used in order to reconstruct population dynamics. The results have confirmed the boom and bust pattern in the Balkan region, and have also shown that these processes happened within the same time frame in the eastern Adriatic (Pilaar Birch, Vander Linden 2017.Figs. 5 and 6).

Additional data are available for the territory of Croatia. Botić presents the results of summed distributions of the Starčevo (Early Neolithic) and Sopot (Late Neolithic) dates from the territory of Croatia (Botic 2016.17, Fig. 4). A sign of possible population growth similar to the one observed in data from neighbouring regions is present. However, it should be noted that the number of dates from this study is very low (23 dates).

It is interesting to note that the peaks from the three curves (Bulgaria, Hungary, Serbia) coincide (Fig. 4), given the usual assumption that the Neolithic gradually spread from south to north. The earliest Neolithic in Serbia and Bulgaria is dated to $\sim 6200$ and $\sim 6100-6050$ cal BC, respectively (Whittle et al. 2002; Krauß et al. 2014). The earliest Körös sites in Hungary are not older than 6000 cal BC (Anders, Siklósi 2012.153). Therefore, it should be expected that population boom in Central and Eastern Balkans should have happened earlier than in the Great Hungarian Plain if the demographic process was the same. Given the small samples in all regions of Southeast Europe and the fact that the SCPD method is a very rough tool, these contradictions should not be given too much weight at this moment, as the precision to discriminate between the shifts of one or two centuries may be lacking in this case.

Given the increasing importance of the research focusing on the relationship between climate changes and cultural dynamics (e.g., Wirtz, Lemmen 2003; Budja 2007; 2015; Gronenborn 2009; Weninger et al. 2009; 2014; Clare, Weninger 2010; Shennan et al. 2013; Lemmen, Wirtz 2012; Botić 2016; Pilaar Birch, Vander Linden 2017), we compared the SCPD curves to a global climate proxy. In order to explore the relationship between climate and population dynamics in the three regions of Southeast Europe, the SCPD curves for Serbia, Hungary and Bulgaria are plotted against the GISP2 core curve (Grootes, Stuiver 1997) (Fig. 4). There is some indication that the troughs after $\sim 5500 \mathrm{cal}$ BC on SCPD curves based on dates from Serbia and Hungary may be related to the reduction in temperature which started somewhat earlier, but no strong sign of covariation is present. Unfortunately, at this point, no high-resolution climate proxies are available for the study region, and a more precise climate reconstruction is not possible. Relying on global proxies such as GISP cores when investigating populations dynamics in the central Balkan area can only be regarded as a general framework for further research.

In order to create a more accurate and precise reconstruction of population dynamics in Southeastern Europe, it is necessary to generate a new sample of radiocarbon dates according to a probabilistic sampling design, which would minimise the re-

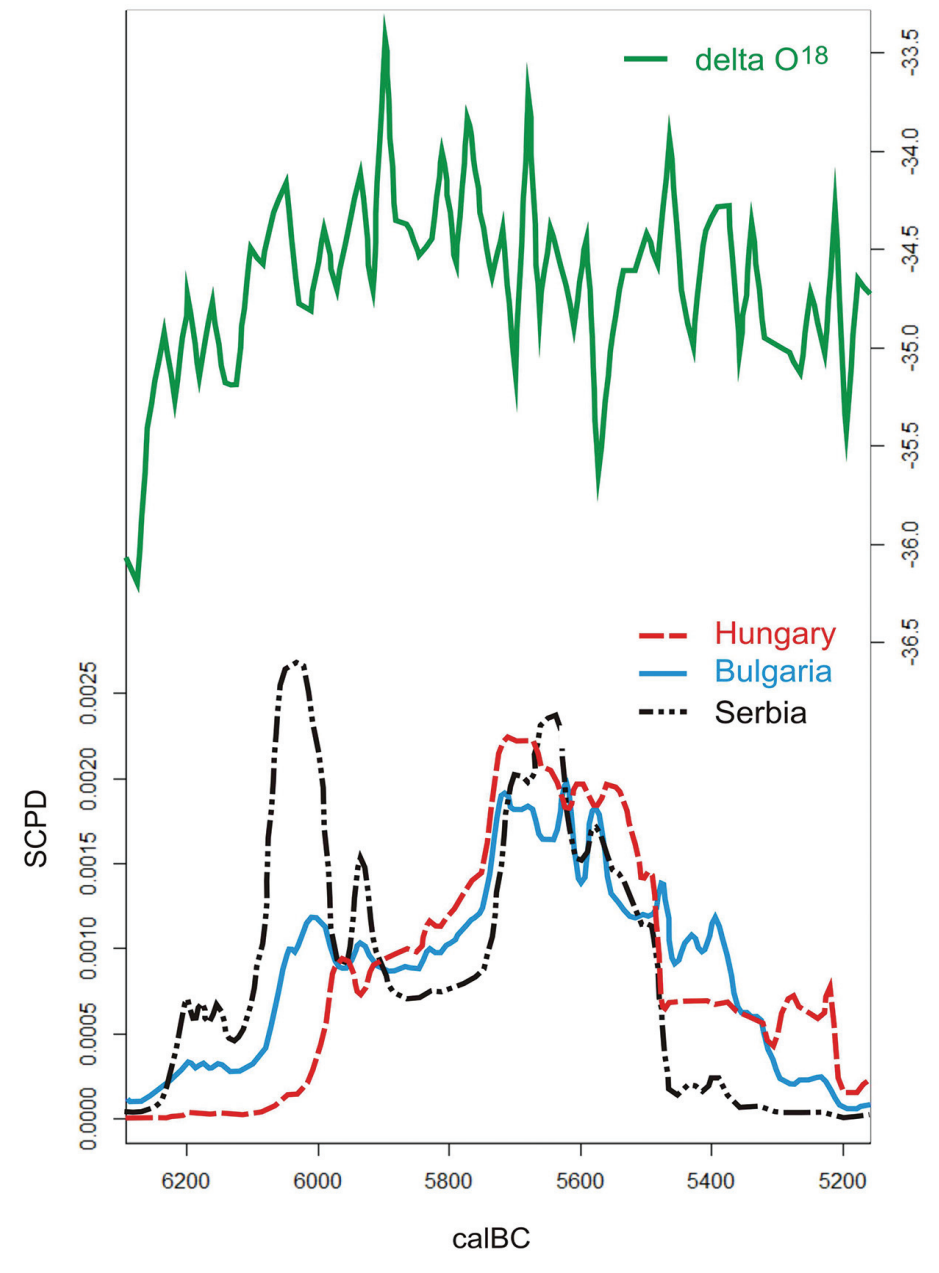

Fig. 4. Climate proxy (raw 8018 curve data from GISP2 core - green solid line) plotted over SCPD curves for Serbia (black dash-dotted line), Bulgaria (blue solid line) and Hungary (red dashed line) 
search bias and increase statistical power. For the region of Central Balkans, the collection of new radiocarbon samples is currently under way by the authors of this paper. This sample is specifically designed for the purposes of population dynamics reconstruction with the SCPD method; an effort is made to approximate a random sample. Therefore, the results presented in this paper should be considered as preliminary and will be further refined when the new data arrive.

\section{Conclusions}

It can be concluded that in the Eastern Balkans and Great Hungarian plain, the shape of the SCPD curve is consistent with the population boom predicted by the NDT theory and empirical results from other parts of Europe and Balkans. No clear influence of climate on population dynamics patterns during the $6^{\text {th }}$ millennium cal BC was detected.

\section{ACKNOWLEDGEMENTS}

This research is a result of the Project "BIRTH: Births, mothers and babies: prehistoric fertility in the Balkans between 10000-5000 BC", funded by the European Research Council (ERC) (https://erc.europa. eu/) under the European Union's Horizon 2020 research and innovation programme (Grant Agreement No. 640557; Principal Investigator: SS). We would like to thank Jugoslav Pendic for his help with Figure 1. We are also grateful to Carsten Lemmen and the anonymous reviewer for their constructive comments, suggestions and criticism. The responsibility for all remaining omissions and errors is exclusively ours.

\section{References}

Ammerman A., Cavalli-Sforza L. 1971. Measuring the Rate of Spread of Early Farming in Europe. Man 6(4): 674688.

1973. A population model for the diffusion of early farming in Europe. In C. Renfrew (ed.), The explanation of culture change: models in prehistory. Duckworth. London: 343-357.

Anders A., Siklósi Z. (eds.) 2012. The First Neolithic Sites in Central/South-East European Transect, Volume III. The Körös Culture in Eastern Hungary. British Archaeological Reports IS 2334. Archaeopress. Oxford.

Bar-Yosef 0. 2004. Guest Editorial: East to West - Agricultural Origins and Dispersal into Europe. Current Anthropology 45: S1-S3.

Bocquet-Appel J-P. 2002. Paleoanthropological Traces of a Neolithic Demographic Transition. Current Anthropology 43(4): 637-650.

2008. Explaining the Neolithic Demographic Transition. In J-P. Bocquet-Appel, 0. Bar-Yosef (eds.), The Neolithic Demographic Transition and its Consequences. Springer. Berlin: 35-55.

2011a. When the World's Population Took Off: The Springboard of the Neolithic Demographic Transition. Science 333(6042): 560-561. http://science.sciencemag. org/content $/ 333 / 6042 / 560$ 2011b. The Agricultural Demographic Transition During and After the Agriculture Inventions. Current Anthropology 52(S4): S497-S510.

2013. Demographic Transitions. In C. Smith (ed.), Encyclopedia of Global Archaeology. Springer Science+ Business Media. New York: 1-8.

Bocquet-Appel J-P., Bar-Yosef 0. (eds.) 2008. The Neolithic Demographic Transition and its Consequences. Springer. Berlin.

Bocquet-Appel J-P., Naji S., Vander Linden M. and Kozłowski J. K. 2009. Detection of diffusion and contact zones of early farming in Europe from the space-time distribution of ${ }^{14} \mathrm{C}$ dates. Journal of Archaeological Science 36(3): $1-14$.

Borić D., Price T. D. 2013. Strontium isotopes document greater human mobility at the start of the Balkan Neolithic. Proceedings of the National Academy of Sciences of the USA 110(9): 3298-3303. http://www.pnas.org/con tent/110/9/3298.full

Botić K. 2016. Climatic influences on appearance and development of Neolithic cultures in southern outskirts of Carpathian basin. Studia Quaternaria 33(1): 11-26. https:// bib.irb.hr/datoteka/811183.s_011_026_opt-2.pdf

Boyadzhiev Y. D. 2009. Early neolithic cultures on the territory of Bulgaria. In I. Gatsov, Y. Boyadzhiev (eds.), The 
First Neolithic Sites in Central/South-East European Transect, Volume I. Early Neolithic Sites on the Territory of Bulgaria. British Archaeological Reports IS 2048. Archaeopress. 0xford: 7-43.

Brami M., Heyd V. 2011. The origins of Europe's first farmers: The role of Hacilar and western Anatolia, fifty years on. Prähistorische Zeitschrift 86(2): 165-206.

Brami M., Zanotti A. 2015. Modelling the initial expansion of the Neolithic out of Anatolia. Documenta Praehistorica 42: 103-116. http://revije.ff.uni-lj.si/DocumentaPrae historica/article/view/42.6

Budja M. 2007. The 8200 calBP 'climate event' and the process of neolithisation in south-eastern Europe. Documenta Praehistorica 34: 191-201. http://revije.ff.uni-lj. si/DocumentaPraehistorica/article/view/34.14

2015. Archaeology and rapid climate changes from the collapse concept to a panarchy interpretative model. Documenta Praehistorica 42: 171-184. http://revije.ff. uni-lj.si/DocumentaPraehistorica/article/view/42.11

Clare L., Weninger B. 2010. Social and biophysical vulnerability of prehistoric societies to Rapid Climate Change. Documenta Praehistorica 37: 283-292. http://revije.ff. uni-li.si/DocumentaPraehistorica/article/view/37.24

Davison K., Dolukhanov P. M., Sarson G. R., Shukurov A. and Zaitseva G. I. 2007. A Pan-European model of the Neolithic. Documenta Praehistorica 34: 139-154. http://re vije.ff.uni-lj.si/DocumentaPraehistorica/article/view/ 34.11

Domboróczki L. 2010. Report on the excavation at Tiszaszólós-Domaháza-puszta and a new model for the spread of the Körös culture. In J. K. Kozłowski, P. Raczky (eds.), Neolithization of the Carpathian Basin: Northernmost distribution of the Starčevo/Körös culture. Kraków-Budapest: $137-176$.

Domboróczki L., Raczky P. 2010. Excavations at IbrányNagyerdô and the northernmost distribution of the Körös culture in Hungary. In J. K. Kozłowski, P. Raczky (eds.), Neolithization of the Carpathian Basin: Northernmost distribution of the Starčevo/Körös culture. Kraków-Budapest: 191-218.

Fort J. 2012. Synthesis between demic and cultural diffusion in the Neolithic transition in Europe. Proceedings of the National Academy of Sciences of the USA 109(46): 18669-18673. http://www.pnas.org/content/109/46/186 69.full

Fort J., Crema E. R. and Madella M. 2015. Modelling Demic and Cultural Diffusion: An Introduction. Human Bio$\log y$ 87(3): 141-149.
Gatsov I., Boyadzhiev Y. (eds.) 2009. The First Neolithic Sites in Central/South-East European Transect, Volume I. Early Neolithic Sites on the Territory of Bulgaria. British Archaeological Reports IS 2048. Archaeopress. Oxford.

Gronenborn D. 2009. Climate fluctuations and trajectories to complexity in the Neolithic: towards a theory. Documenta Praehistorica 36: 97-110. http://revije.ff.uni-lj. si/DocumentaPraehistorica/article/view/36.5

Grootes P., Stuiver M. 1997. Oxygen 18/16 variability in Greenland snow and ice with $10^{-3}$ to $10^{-5}$ year time resolution. Journal of Geophysical Research: Oceans (19782012), 102(C12): 26455-26470.

Gurova M., Bonsall K. 2014. 'Pre-Neolithic' in Southeast Europe: a Bulgarian perspective. Documenta Praehistorica 41: 95-109. http://revije.ff.uni-li.si/DocumentaPraehi storica/article/view/41.5/2568

Haak W. and 18 co-authors. 2010. Ancient DNA from European Early Neolithic farmers reveals their Near Eastern affinities. PLOS Biology 8(11): e1000536. doi: 10.1371/ journal.pbio.1000536 PMID: 21085689 http://journals. plos.org/plosbiology/article?id=10.1371/journal.pbio.10 00536\#s2

Hofmanová Z. and 38 co-authors. 2016. Early farmers from across Europe directly descended from Neolithic Aegeans. Proceedings of the National Academy of Sciences of the USA 113(25): 6886-6891. http://www.pnas. org/content/113/25/6886.full

Krauß R., Elenski N., Weninger B., Clare L., Çakirlar C. and Zidarov P. 2014. Beginnings of the Neolithic in Southeast Europe: the Early Neolithic sequence and absolute dates from Džuljunica-Smărdeš (Bulgaria). Documenta Praehistorica 41: 51-77. http://revije.ff.uni-lj.si/Documen taPraehistorica/article/view/41.3

Lemmen C., Wirtz K. W. 2014. On the sensitivity of the simulated European Neolithic transition to climate extremes. Journal of Archaeological Science 51: 65-72.

Lemmen C., Gronenborn D. and Wirtz K. W. 2011. A simulation of the Neolithic transition in Western Eurasia. Journal of Archaeological Science 38: 3459-3470.

Mathieson I. and 37 co-authors. 2015. Genome-wide patterns of selection in 230 ancient Eurasians. Nature; advance online publication. doi: 10.1038/nature 16152

Oross K., Siklósi Z. 2012. Relative and absolute chronology of the Early Neolithic of the Great Hungarian Plain. In A. Anders, Z. Siklósi (eds.), The First Neolithic Sites in Central/South-East European Transect, Volume III. The Körös Culture in Eastern Hungary. British Archaeological Reports IS 2334. Archaeopress. Oxford: 129-159. 
Özdoğan M. 2014. A new look at the introduction of the Neolithic way of life in Southeastern Europe. Changing paradigms of the expansion of the Neolithic way of life. Documenta Praehistorica 41: 33-49. http://revije.ff.unilj. si/DocumentaPraehistorica/article/view/41.2

Paluch T. 2012. Characteristics of the Körös culture in the southern section of the Great Hungarian Plain. In A. Andersand, Z. Siklósi (eds.), The First Neolithic Sites in Central/South-East European Transect, Volume III. The Körös Culture in Eastern Hungary. British Archaeological Reports IS 2334. Archaeopress. Oxford: 49-52.

Parnell A. 2014. Bchron: Radiocarbon dating, age-depth modelling, relative sea level rate estimation, and non-parametric phase modelling. R package version 4.0. 2014

Perlès C., Quiles A. and Valladas H. 2013. Early seventhmillennium AMS dates from domestic seeds in the Initial Neolithic at Franchthi Cave (Argolid, Greece). Antiquity 87(338): 1001-1015.

Pilaar Birch S. E., Vander Linden M. 2017. A long hard road... Reviewing the evidence for environmental change and population history in the eastern Adriatic and western Balkans during the Late Pleistocene and Early Holocene. Quaternary International. http://dx.doi.org/10.1016/j. quaint.2016.12.035

Pinhasi R., Fort J. and Ammerman A. J. 2005. Tracing the origin and spread of agriculture in Europe. PLOS Biology 3(12): e2220-e2228. http://journals.plos.org/plosbiology/ article?id=10.1371/journal.pbio.0030410

Pinhasi R., Thomas M. G., Hofreiter M., Currat M. and Burger J. 2012. The genetic history of Europeans. Trends in Genetics 28(10): 496-505. doi: 10.1016/j.tig.2012.06.006 PMID: 22889475

Porčić M., Blagojević T. and Stefanović S. 2016. Demography of the Early Neolithic Population in Central Balkans: Population Dynamics Reconstruction Using Summed Radiocarbon Probability Distributions. PLOS ONE 11(8): e0160832. http://journals.plos.org/plosone/article?id=10. 1371/journal.pone.0160832

R Core Team 2014. R: A language and environment for statistical computing. R Foundation for Sratistical Computing, Viena, Austria. URL http://R-project.org/

Reimer P. J. and 29 co-authors. 2013. IntCal13 and Marine13 Radiocarbon Age Calibration Curves 0-50,000 Years cal BP. Radiocarbon 55(4): 1869-1887.

Rick J. W. 1987. Dates as Data: An Examination of the Peruvian Preceramic Radiocarbon Record. American Antiquity 52(1): 55-73.
Shennan S., Edinborough K. 2007. Prehistoric population history: from the Late Glacial to the Late Neolithic in Central and Northern Europe. Journal of Archaeological Science 34: 1339-1345.

Shennan S., Downey S. S., Timpson A., Edinborough K., Colledge S., Kerig T., Manning, K. and Thomas M. G. 2013. Regional population collapse followed initial agriculture booms in mid-Holocene Europe. Nature Communications 4: 2486. http://www.nature.com/articles/ncom ms3486

Silva F., Steele J. 2014. New methods for reconstructing geographical effects on dispersal rates and routes from large-scale radiocarbon databases. Journal of Archaeological Science 52: 609-620.

Szécsényi-Nagy A. and 27 co-authors. 2015. Tracing the genetic origin of Europe's first farmers reveals insights into their social organization. Proceedings of the Royal Society of London B: Biological Sciences 282(1805): 20150339. http://rspb.royalsocietypublishing.org/content/ 282/1805/20150339

Timpson A., Colledge S., Crema E., Edinborough K., Kerig T., Manning K., Thomas, M. G. and Shennan S. 2014. Reconstructing regional population fluctuations in the European Neolithic using radiocarbon dates: a new case-study using an improved method. Journal of Archaeological Science 52: 549-557. http://www.sciencedirect.com/sci ence/article/pii/S0305440314002982

Timpson A., Manning K. and Shennan S. 2015. Inferential mistakes in population proxies: A response to Torfing's "Neolithic population and summed probability distribution of ${ }^{14} \mathrm{C}$-dates". Journal of Archaeological Science 63: 199-202. doi:http://dx.doi.org/10.1016/j.jas.2015.08.018

Tringham R. 2000. Southeastern Europe in the transition to agriculture in Europe: bridge, buffer or mosaic. In T. D. Price (ed.), Europe's First Farmers. Cambridge University Press. Cambridge: 19-56.

Weninger B. and 18 co-authors. 2009. The Impact of Rapid Climate Change on Prehistoric Societies during the Holocene inthe Eastern Mediterranean. Documenta Praehistorica 36: 7-59. http://revije.ff.uni-lj.si/DocumentaPrae historica/article/view/36.2

Weninger B., Clare L., Gerritsen F., Horejs B., Krauß R., Linstädter J., Özbal R. and Rohlling E. J. 2014. Neolithisation of the Aegean and Southeast Europe during the 6600-6000 cal BC period of Rapid Climate Change. Documenta Praehistorica 41: 1-31. http://revije.ff.uni-lj.si/ DocumentaPraehistorica/article/view/41.1 
Wirtz K. W., Lemmen C. 2003. A global dynamic model for the Neolithic transition. Climatic change 59: 333-367.

Whittle A., Bartosiewicz L., Borić D., Pettitt P. and Richards M. 2002. In the beginning: new radiocarbon dates for the
Early Neolithic in northern Serbia and south-east Hungary. Antaeus (25): 63-117.

Williams A. N. 2012. The use of summed radiocarbon probability distributions in archaeology: a review of methods. Journal of Archaeological Science 39: 578-589.

$\therefore$

\section{Appendix 1}

\section{List of sites from the territory of Hungary and Bulgaria, with radiocarbon dates used in this study}

\begin{tabular}{|c|c|c|c|c|c|c|}
\hline \multicolumn{7}{|c|}{ HUNGARY } \\
\hline $\begin{array}{l}\text { Site } \\
\text { (No. on the Fig. 1) }\end{array}$ & Coordinates & Lab. No & $\begin{array}{l}\text { Uncal. } \\
\text { BP }\end{array}$ & $\begin{array}{l}\text { St. } \\
\text { error }\end{array}$ & Cal BC & Reference \\
\hline $\begin{array}{l}\text { Battonya-Basarága } \\
\text { (17) }\end{array}$ & $\begin{array}{l}45^{\circ} 59^{\prime} 37.84^{\prime \prime} \mathrm{N} \\
21^{\circ} 28^{\prime} 10.12^{\prime \prime} \mathrm{E}\end{array}$ & $B M-1862 R$ & 6710 & 110 & $5840(95.4 \%) 5473$ & $\begin{array}{l}\text { Bowman et al. 1990.73; Hor- } \\
\text { váth, Hertelendi } 1994.123\end{array}$ \\
\hline Deszk-Olajkút (18) & $\begin{array}{l}46^{\circ} 13^{\prime} 43.75^{\prime \prime} \mathrm{N} \\
20^{\circ} 14^{\prime} 34.04^{\prime \prime} \mathrm{E}\end{array}$ & OxA-9396 & 7030 & 50 & $6010(95.4 \%) 5796$ & Whittle et al. 2002.111, 115 \\
\hline Deszk-Olajkút & & $B \ln -581$ & 6605 & 100 & $5709(95.4 \%) 5374$ & Quitta, Kohl 1969.240 \\
\hline Deszk-Olajkút & & Bln-584 & 6540 & 100 & $5643(95.4 \%) 5317$ & Quitta, Kohl 1969.240 \\
\hline Deszk-Olajkút & & $B \ln -583$ & 6410 & 100 & $5613(95.4 \%) 5083$ & Quitta, Kohl 1969.240 \\
\hline Deszk-Olajkút & & $B \ln -582 a$ & 6390 & 100 & $5551(95.5 \%) 5078$ & Quitta, Kohl 1969.240 \\
\hline Deszk-Olajkút & & $B \ln -582$ & 6260 & 100 & $5469(95.4 \%) 4994$ & Quitta, Kohl 1969.240 \\
\hline Deszk-Olajkút & & OxA-9376 & 6225 & 55 & $5315(95.4 \%) 5040$ & Whittle et al. 2002.111, 115 \\
\hline $\begin{array}{l}\text { Dévaványa-Katalszeg } \\
\text { (19) }\end{array}$ & $\begin{array}{l}47^{\circ} 0^{\prime} 56.39 " \mathrm{~N} \\
20^{\circ} 57^{\prime} 35.72 " \mathrm{E}\end{array}$ & $B \ln -86$ & 6370 & 100 & $5524(95.4 \%) 5070$ & Kohl, Quitta 1963.300 \\
\hline $\begin{array}{l}\text { Dévaványa- } \\
\text { Réhelyi gát (38) }\end{array}$ & $\begin{array}{l}47^{\circ} 4 \text { '9.37"N } \\
20^{\circ} 55^{\prime} 8.78 " \mathrm{E}\end{array}$ & Bln-1379 & 6640 & 60 & $5657(95.4 \%) 5482$ & Oross, Siklosi 2012.Tab. 1 \\
\hline Ecsegfalva $23(20)$ & $\begin{array}{l}47^{\circ} 8^{\prime} 34.42^{\prime \prime} \mathrm{N} \\
20^{\circ} 55^{\prime} 17.19^{\prime \prime} \mathrm{E}\end{array}$ & OxA-9329 & 6950 & 45 & $5974(95.4 \%) 5733$ & Whittle et al. 2002.110, 115 \\
\hline Ecsegfalva 23 & & OxA-11871 & 6930 & 40 & $5899(95.4 \%) 5726$ & Bronk Ramsey et al. 2007.175 \\
\hline Ecsegfalva 23 & & OxA-9335 & 6920 & 50 & $5969(95.4 \%) 5716$ & Whittle et al. 2002.110, 115 \\
\hline Ecsegfalva 23 & & OxA-9526 & 6915 & 50 & $5970(95.4 \%) 5712$ & Whittle et al. 2002.110, 115 \\
\hline Ecsegfalva 23 & & OxA-11983 & 6915 & 36 & $5881(95.4 \%) 5726$ & Bronk Ramsey et al. 2007.175 \\
\hline Ecsegfalva 23 & & OxA-10500 & 6900 & 60 & 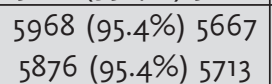 & Bronk Ramsey et al. 2007.175 \\
\hline Ecsegfalva 23 & & OxA-11984 & 6893 & 36 & $5876(95.4 \%) 5713$ & Bronk Ramsey et al. 2007.175 \\
\hline Ecsegfalva 23 & & OxA-12654 & 6889 & 36 & $5874(95.4 \%) 5710$ & Bronk Ramsey et al. 2007.176 \\
\hline Ecsegfalva 23 & & OxA-10501 & 6885 & 50 & 5881 ו $567.4 \%$ & Bronk Ramsey et al. 2007.176 \\
\hline Ecsegfalva 23 & & OxA-9327 & 6870 & 50 & $5877(95.4 \%) 5661$ & Whittle et al. 2002.110, 115 \\
\hline Ecsegfalva 23 & & OxA-11845 & 6865 & 40 & $5840(95.4 \%) 5667$ & Bronk Ramsey et al. 2007.175 \\
\hline Ecsegfalva 23 & & OxA-9333 & 6860 & 45 & $5844(95.4 \%) 5658$ & $\begin{array}{l}\text { Whittle et al. 2002.110, 115; } \\
\text { Bronk Ramsey et al. 2007.175 }\end{array}$ \\
\hline Ecsegfalva 23 & & OxA-9334 & 6855 & 50 & $5844(95.4 \%) 5644$ & ibid. \\
\hline Ecsegfalva 23 & & OxA-10505 & 6845 & 50 & $5838(95.4 \%) 5643$ & Bronk Ramsey et al. 2007.176 \\
\hline Ecsegfalva 23 & & OxA-12655 & 6830 & 35 & $5777(95.4 \%) 5642$ & Bronk Ramsey et al. 2007.176 \\
\hline Ecsegfalva 23 & & OxA-12860 & 6826 & 41 & $5787(95.4 \%) 5637$ & Bronk Ramsey et al. 2007.176 \\
\hline Ecsegfalva 23 & & OxA-11863 & 6825 & 45 & $5796(95.4 \%) 5633$ & Bronk Ramsey et al. 2007.175 \\
\hline Ecsegfalva 23 & & OxA-12859 & 6818 & 44 & $5783(95.4 \%) 5632$ & Bronk Ramsey et al. 2007.175 \\
\hline Ecsegfalva 23 & & OxA-9328 & 6815 & 50 & $5797(95.4 \%) 5627$ & $\begin{array}{l}\text { Whittle et al. 2002.110, 115; } \\
\text { Bronk Ramsey et al. 2007.175 }\end{array}$ \\
\hline Ecsegfalva 23 & & OxA-9331 & 6815 & 45 & $5778(95.4 \%) 5631$ & ibid. \\
\hline
\end{tabular}




\begin{tabular}{|c|c|c|c|c|c|c|}
\hline $\begin{array}{l}\text { Site } \\
\text { (No. on the Fig. 1) }\end{array}$ & Coordinates & Lab. No & $\begin{array}{l}\text { Uncal. } \\
\text { BP }\end{array}$ & $\begin{array}{c}\text { St. } \\
\text { error }\end{array}$ & Cal BC & Reference \\
\hline Ecsegfalva 23 & & OxA-9332 & 6810 & 45 & 5771 (95.4\% 5629 & $\begin{array}{l}\text { Whittle et al. 2002.110, 115; } \\
\text { Bronk Ramsey et al. } 2007.175\end{array}$ \\
\hline Ecsegfalva 23 & & OxA-11982 & 6806 & 39 & $5746(95.4 \%) 5632$ & Bronk Ramsey et al. 2007.175 \\
\hline Ecsegfalva 23 & & OxA-9330 & 6795 & 50 & 5771 (95.4\%) 5621 & $\begin{array}{l}\text { Whittle et al. 2002.110, } 115 \\
\text { Bronk Ramsey et al. } 2007.176\end{array}$ \\
\hline Ecsegfalva 23 & & $\begin{array}{l}\text { OxA-X- } \\
2040-07\end{array}$ & 6787 & 37 & $5731(95.4 \%) 5631$ & Bronk Ramsey et al. 2007.176 \\
\hline Ecsegfalva 23 & & OxA-13511 & 6785 & 45 & $5739(95.4 \%) 5624$ & Bronk Ramsey et al. 2007.175 \\
\hline Ecsegfalva 23 & & OxA-12858 & 6782 & 42 & $5733(95.4 \%) 5627$ & Bronk Ramsey et al. 2007.175 \\
\hline Ecsegfalva 23 & & OxA-11850 & 6780 & 50 & $5752(95.4 \%) 5617$ & Bronk Ramsey et al. 2007.175 \\
\hline Ecsegfalva 23 & & $\begin{array}{l}\text { OxA-X- } \\
2040-09\end{array}$ & 6780 & 39 & $5728(95.4 \%) 5630$ & Bronk Ramsey et al. 2007.175 \\
\hline Ecsegfalva 23 & & $\begin{array}{l}\text { OxA-X- } \\
2040-08\end{array}$ & 6775 & 37 & $5726(95.4 \%) 5629$ & Bronk Ramsey et al. 2007.175 \\
\hline Ecsegfalva 23 & & OxA-12854 & 6774 & 45 & $5736(95.4 \%) 5621$ & Bronk Ramsey et al. 2007.175 \\
\hline Ecsegfalva 23 & & OxA-11868 & 6750 & 45 & $5728(95.4 \%) 5571$ & Bronk Ramsey et al. 2007.176 \\
\hline Ecsegfalva 23 & & OxA-13510 & 6731 & 43 & $5720(95.4 \%) 5563$ & Bronk Ramsey et al. 2007.176 \\
\hline Ecsegfalva 23 & & OxA-12140 & 6729 & 32 & $5711(95.4 \%) 5571$ & Bronk Ramsey et al. 2007.176 \\
\hline Ecsegfalva 23 & & OxA-9325 & 6690 & 50 & $5707(95.4 \%) 5526$ & $\begin{array}{l}\text { Whittle et al. 2002.110, } 115 \\
\text { Bronk Ramsey et al. } 2007.176\end{array}$ \\
\hline Ecsegfalva 23 & & OxA-10148 & 6665 & 50 & $5664(95.4 \%) 5491$ & ibid. \\
\hline Ecsegfalva 23 & & OxA-11849 & 6660 & 40 & $5646(95.4 \%) 5512$ & Bronk Ramsey et al. 2007.176 \\
\hline Ecsegfalva 23 & & OxA-12855 & 6596 & 42 & $5617(95.4 \%) 5483$ & Bronk Ramsey et al. 2007.175 \\
\hline Endröd 35 (21) & $\begin{array}{l}46^{\circ} 52^{\prime} 8.86 " \mathrm{~N} \\
20^{\circ} 51^{\prime} 23.05^{\prime \prime} \mathrm{E}\end{array}$ & Bln-1940 & 6615 & 60 & $5635(95.4 \%) 5478$ & Oross, Siklosi 2012.Tab. 1 \\
\hline Endrőd 35 & & Bln-1960 & 6415 & 60 & $5488(95.4 \%) 5235$ & Oross, Siklosi 2012.Tab. 1 \\
\hline Endrőd 35 & & BM-1864R & 6180 & 110 & $5369(95.4 \%) 4840$ & Bowman et al. 1990.73 \\
\hline Endrőd 39 (22) & $\begin{array}{l}46^{\circ} 58^{\prime} 59.01 " \mathrm{~N} \\
20^{\circ} 45^{\prime} 33.377^{\prime \prime} \mathrm{E}\end{array}$ & BM-1868R & 6970 & 110 & $6047(95.4 \%) 5662$ & $\begin{array}{l}\text { Bowman et al. 1990.73; } \\
\text { Horváth, Hertelendi } 1994.122 \\
\text { (with Lab no. BM-1668R) }\end{array}$ \\
\hline Endrőd 39 & & BM-1863R & 6950 & 140 & 6083 (95.4\%) 5571 & $\begin{array}{l}\text { Bowman et al. } 1990.73 ; \\
\text { Horváth, Hertelendi } 1994.122\end{array}$ \\
\hline Endrőd 39 & & BM-1870R & 6950 & 120 & $6034(95.4 \%) 5635$ & $\begin{array}{l}\text { Bowman et al. 1990.73; } \\
\text { Horváth, Hertelendi } 1994.122 \\
\text { (with Lab no. BM-1971R) }\end{array}$ \\
\hline Endrőd 39 & & BM-187וR & 6830 & 120 & $5982(95.4 \%) 5540$ & $\begin{array}{l}\text { Bowman et al. } 1990.73 ; \\
\text { Horváth, Hertelendi } 1994.122\end{array}$ \\
\hline Endrőd 39 & & Bln-1941 & 6785 & 55 & $5777(95.4 \%) 5573$ & Oross, Siklosi 2012.Tab. 1 \\
\hline Endrőd 119 (23) & $\begin{array}{l}46^{\circ} 56^{\prime} 2.43^{\prime \prime} \mathrm{N} \\
20^{\circ} 37^{\prime} 53.42 " \mathrm{E}\end{array}$ & OxA-9587 & 6915 & 45 & $5899(95.4 \%) 5716$ & Whittle et al. 2002.110, 115 \\
\hline Endrőd 119 & & OxA-9583 & 6895 & 45 & $5890(95.4 \%) 5676$ & Whittle et al. 2002.110, 115 \\
\hline Endröd 119 & & OxA-9588 & 6855 & 45 & $5842(95.4 \%) 5657$ & Whittle et al. 2002.110, 115 \\
\hline Endrőd 119 & & OxA-9586 & 6850 & 45 & $5839(95.4 \%) 5650$ & Whittle et al. 2002.110, 115 \\
\hline Endrőd 119 & & OxA-9582 & 6825 & 45 & $5796(95.4 \%) 5633$ & Whittle et al. 2002.110, 115 \\
\hline Endröd 119 & & OxA-9584 & 6825 & 45 & $5796(95.4 \%) 5633$ & Whittle et al. 2002.110, 115 \\
\hline Endröd 119 & & OxA-9590 & 6815 & 50 & $5797(95.4 \%) 5627$ & Whittle et al. 2002.110, 115 \\
\hline Endrőd 119 & & OxA-9585 & 6795 & 50 & $5771(95.4 \%) 5621$ & Whittle et al. 2002.110, 115 \\
\hline Endrőd 119 & & OxA-9589 & 6720 & 45 & $5717(95.4 \%) 5559$ & Whittle et al. 2002.110, 115 \\
\hline $\begin{array}{l}\text { Endrőd-Varnyai- } \\
\text { tanya (24) }\end{array}$ & $\begin{array}{l}46^{\circ} 54^{\prime} 54.34 " \mathrm{~N} \\
20^{\circ} 46^{\prime} 37.73^{\prime \prime} \mathrm{E}\end{array}$ & OxA-9395 & 6595 & 50 & $5619(95.4 \%) 5481$ & Whittle et al. 2002.111, 116 \\
\hline $\begin{array}{l}\text { Gyálarét-Szilágyi } \\
\text { major (25) }\end{array}$ & $\begin{array}{l}46^{\circ} 14^{\prime} 32.24^{\prime \prime} \mathrm{N} \\
20^{\circ} 8 \text { '50.49" }\end{array}$ & Bln-75 & 7090 & 100 & $6206(95.4 \%) 5746$ & $\begin{array}{l}\text { Kohl, Quitta 1963.299-300; } \\
\text { 1964.315; Horváth, Herte- } \\
\text { lendi } 1994.122\end{array}$ \\
\hline $\begin{array}{l}\text { Hódmezővásárhely- } \\
\text { Kotacpart-Vata-tanya } \\
\text { (26) }\end{array}$ & $\begin{array}{l}46^{\circ} 23^{\prime} 37.19^{\prime \prime} \mathrm{N} \\
20^{\circ} 14^{\prime} 41.87^{\prime \prime} \mathrm{E}\end{array}$ & Bln-115 & 6450 & 100 & $5613(95.4 \%) 5224$ & $\begin{array}{l}\text { Kohl, Quitta 1963.299-300; } \\
1964.315-316\end{array}$ \\
\hline
\end{tabular}




\begin{tabular}{|c|c|c|c|c|c|c|}
\hline $\begin{array}{l}\text { Site } \\
\text { (No. on the Fig. 1) }\end{array}$ & Coordinates & Lab. No & $\begin{array}{l}\text { Uncal. } \\
\text { BP }\end{array}$ & $\begin{array}{l}\text { St. } \\
\text { error }\end{array}$ & Cal BC & Reference \\
\hline Ibrány-Nagyerdő (27) & $\begin{array}{l}48^{\circ} 8 ' 3.32^{\prime \prime} \mathrm{N} \\
21^{\circ} 42^{\prime} 51.46^{\prime \prime} \mathrm{E}\end{array}$ & Poz-28216 & 6630 & 40 & $5626(95.4 \%) 5491$ & $\begin{array}{l}\text { Domboróczki, Raczky } 2010 . \\
214\end{array}$ \\
\hline Ibrány-Nagyerdő & & Poz-28214 & 6570 & 40 & $5615(95.4 \%) 5475$ & Domboróczki, Raczky 2010.214 \\
\hline Maroslele-Pana (28) & $\begin{array}{l}46^{\circ} 17^{\prime} 58.53^{\prime \prime} \mathrm{N} \\
20^{\circ} 21^{\prime} 17.99 " \mathrm{E}\end{array}$ & OxA-9399 & 6965 & 50 & $5981(95.4 \%) 5736$ & Whittle et al. 2002.111, 115 \\
\hline Maroslele-Pana & & OxA-10149 & 6845 & 50 & $5838(95.4 \%) 5643$ & Whittle et al. 2002.111, 115 \\
\hline Maroslele-Pana & & OxA-9401 & 6780 & 50 & $5752(95.4 \%) 5617$ & Whittle et al. 2002.111, 115 \\
\hline Maroslele-Pana & & OxA-9400 & 6740 & 50 & $5730(95.4 \%) 5561$ & Whittle et al. 2002.111, 115 \\
\hline Méhtelek-Nádas (29) & $\begin{array}{l}47^{\circ} 55^{\prime} 22.39^{\prime \prime} \mathrm{N} \\
22^{\circ} 49^{\prime} 57.54^{\prime \prime} \mathrm{E}\end{array}$ & Bln-1331 & 6835 & 60 & $5843(95.4 \%) 5629$ & $\begin{array}{l}\text { Kalicz, Makkay 1977.23; Hor- } \\
\text { váth, Hertelendi 1994.122; } \\
\text { Raczky et al. } 2010.164\end{array}$ \\
\hline Méhtelek-Nádas & & Bln-1332 & 6655 & 60 & $5665(95.4 \%) 5484$ & ibid. \\
\hline Méhtelek-Nádas & & GrN-6897 & 6625 & 50 & $5628(95.4 \%) 5486$ & ibid. \\
\hline $\begin{array}{l}\text { Nagykörü-Tsz } \\
\text { Gyümölcsös (30) }\end{array}$ & $\begin{array}{l}47^{\circ} 16^{\prime} 28.34^{\prime \prime} \mathrm{N} \\
20^{\circ} 26^{\prime} 30.85^{\prime \prime} \mathrm{E}\end{array}$ & VERA-3476 & 7065 & 35 & $6016(95.4 \%) 5883$ & Raczky et al. 2010.164 \\
\hline$-11-$ & & Poz-2346o & 7040 & 40 & $6006(95.4 \%) 5842$ & Gulyás et al. 2010.1462 \\
\hline$-11-$ & & Poz-26328 & 6970 & 40 & $5978(95.4 \%) 5747$ & Raczky et al. 2010.164 \\
\hline$-11-$ & & Poz-26327 & 6940 & 40 & $5966(95.4 \%) 5730$ & Raczky et al. 2010.164 \\
\hline$-11-$ & & Poz-23317 & 6890 & 40 & $5882(95.4 \%) 5707$ & Gulyás et al. 2010.1462 \\
\hline$-11-$ & & VERA-3474 & 6890 & 35 & $5873(95.4 \%) 5712$ & Raczky et al. 2010.164 \\
\hline$-11-$ & & Poz-26325 & 6860 & 40 & $5838(95.4 \%) 5666$ & Raczky et al. 2010.164 \\
\hline$-11-$ & & VERA-3540 & 6850 & 35 & $5833(95.4 \%) 5661$ & Raczky et al. 2010.164 \\
\hline$-11-$ & & VERA-3052 & 6755 & 40 & $5726(95.4 \%) 5618$ & Raczky et al. 2010.164 \\
\hline $\begin{array}{l}\text { Pitvaros-Viztározó } \\
\text { (31) }\end{array}$ & $\begin{array}{l}46^{\circ} 18^{\prime} 1.09 " \mathrm{~N} \\
20^{\circ} 44^{\prime} 32.98^{\prime \prime} \mathrm{E}\end{array}$ & OxA-9336 & 7060 & 45 & $6018(95.4 \%) 5845$ & Whittle et al. 2002.110, 115 \\
\hline Pitvaros-Viztározó & & OxA-9393 & 6940 & 50 & $5974(95.4 \%) 5726$ & Whittle et al. 2002.110, 115 \\
\hline Pitvaros-Viztározó & & OxA-9392 & 6885 & 50 & $5881(95.4 \%) 5671$ & Whittle et al. 2002.110, 115 \\
\hline Röszke-Lúdvár (32) & $\begin{array}{l}46^{\circ} 12^{\prime} 52.36^{\prime \prime} \mathrm{N} \\
19^{\circ} 56^{\prime} 1.82^{\prime \prime} \mathrm{E}\end{array}$ & Deb-2730 & 6972 & 59 & $5983(95.4 \%) 5738$ & Horváth, Hertelendi 1994.122 \\
\hline Szajol-Felsőföld (33) & $\begin{array}{l}47^{\circ} 10^{\prime} 12.34 " \mathrm{~N} \\
20^{\circ} 177^{\prime} 51.28^{\prime \prime} \mathrm{E}\end{array}$ & VERA-3531 & 6805 & 35 & $5738(95.4 \%) 5638$ & Raczky 2006.383 \\
\hline Szajol-Felsőföld & & VERA-3051 & 6725 & 35 & $5713(95.4 \%) 5566$ & Raczky 2006.383 \\
\hline Szajol-Felsőföld & & VERA-3534 & 6620 & 35 & $5621(95.4 \%) 5491$ & Raczky 2006.383 \\
\hline Szarvas 23 (34) & $\begin{array}{l}46^{\circ} 51^{\prime \prime 19.61 " N} \\
20^{\circ} 35^{\prime} 1.11 " \mathrm{E}\end{array}$ & OxA-9375 & 6855 & 55 & 587 ו $585.4 \%$ ) 5639 & Whittle et al. 2002.111-115 \\
\hline Szarvas 23 & & BM-1866R & 6780 & 110 & $5894(95.4 \%) 5491$ & Bowman et al. 1990.73 \\
\hline $\begin{array}{l}\text { Szentpéterszeg- } \\
\text { Körtvélyes (35) }\end{array}$ & $\begin{array}{l}47^{\circ} 14^{\prime} 20.46^{\prime \prime} \mathrm{N} \\
21^{\circ} 35^{\prime} 42.10^{\prime \prime} \mathrm{E}\end{array}$ & Bln-2578 & 6800 & 60 & $5835(95.4 \%) 5617$ & Oross, Siklosi 2012.Tab. 1 \\
\hline Szolnok-Szanda (36) & $\begin{array}{l}47^{\circ} 7 ' 12.70 " \mathrm{~N} \\
20^{\circ} 11 ' 57.79 " \mathrm{E}\end{array}$ & Bln-1938 & 7005 & 80 & $6018(95.4 \%) 5732$ & Oross, Siklosi 2012.Tab. 1 \\
\hline Szolnok-Szanda & & $B \ln -1946$ & 7005 & 80 & $6018(95.4 \%) 5732$ & Oross, Siklosi 2012.Tab. 1 \\
\hline Szolnok-Szanda & & $B \ln -2576$ & 6940 & 60 & $5981(95.4 \%) 5718$ & Oross, Siklosi 2012.Tab. 1 \\
\hline Szolnok-Szanda & & Poz-37861 & 6910 & 40 & $5886(95.4 \%) 5721$ & Oross, Siklosi 2012.Tab. 1 \\
\hline Szolnok-Szanda & & OxA-23754 & 6859 & 34 & $5836(95.4 \%) 5667$ & Oross, Siklosi 2012.Tab. 1 \\
\hline Szolnok-Szanda & & $B \ln -2577$ & 6790 & 70 & $5837(95.4 \%) 5564$ & Oross, Siklosi 2012.Tab. 1 \\
\hline Szolnok-Szanda & & Poz-3786o & 6770 & 40 & $5726(95.4 \%) 5626$ & Oross, Siklosi 2012.Tab. 1 \\
\hline Szolnok-Szanda & & OxA-23756 & 6713 & 33 & $5707(95.4 \%) 5562$ & Oross, Siklosi 2012.Tab. 1 \\
\hline Szolnok-Szanda & & OxA-23755 & 6713 & 32 & $5707(95.4 \%) 5562$ & Oross, Siklosi 2012.Tab. 1 \\
\hline Szolnok-Szanda & & OxA-23753 & 6688 & 35 & $5665(95.4 \%) 5541$ & Oross, Siklosi 2012.Tab. 1 \\
\hline Szolnok-Szanda & & OxA-23752 & 6554 & 32 & $5606(95.4 \%) 5474$ & Oross, Siklosi 2012.Tab. 1 \\
\hline $\begin{array}{l}\text { Tiszaszőlős-Doma- } \\
\text { háza-puszta (37) }\end{array}$ & $\begin{array}{l}47^{\circ} 10^{\prime} 53.07 " \mathrm{~N} \\
18^{\circ} 59^{\prime} 18.34^{\prime \prime} \mathrm{E}\end{array}$ & Deb-1189o & 6920 & 50 & 5969 (95.4\%) 5716 & $\begin{array}{l}\text { Domboróczki, Raczky } 2010 b . \\
\text { 152, Tab. } 1\end{array}$ \\
\hline$-11-$ & & OxA-20238 & 6789 & 37 & 5731 (95.4\%) 5632 & ibid. \\
\hline$-11-$ & & Deb-11902 & 6780 & 65 & $5807(95.4 \%) 5561$ & ibid. \\
\hline$-11-$ & & OxA-20237 & 6776 & 34 & $5724(95.4 \%) 5631$ & ibid. \\
\hline
\end{tabular}


Tamara Blagojević, Marko Porčić, Kristina Penezić and Sofija Stefanović

\begin{tabular}{|c|c|c|c|c|c|c|}
\hline $\begin{array}{l}\text { Site } \\
\text { (No. on the Fig. 1) }\end{array}$ & Coordinates & Lab. No & $\begin{array}{l}\text { Uncal. } \\
\text { BP }\end{array}$ & $\begin{array}{l}\text { St. } \\
\text { error }\end{array}$ & Cal BC & Reference \\
\hline $\begin{array}{l}\text { Tiszaszőlős-Doma- } \\
\text { háza-puszta }\end{array}$ & & OxA-20239 & 6775 & 40 & $5729(95.4 \%) 5627$ & $\begin{array}{l}\text { Domboróczki, Raczky } 2010 b . \\
\text { 152, Tab. } 1\end{array}$ \\
\hline$-11-$ & & Deb-11804 & 6740 & 60 & $5736(95.4 \%) 5547$ & ibid. \\
\hline$-11-$ & & OxA-20236 & 6673 & 35 & $5657(95.4 \%) 5531$ & ibid. \\
\hline$-11-$ & & Deb-12962 & 6657 & 65 & $5701(95.4 \%) 5481$ & ibid. \\
\hline$-11-$ & & Deb-11898 & 6550 & 95 & $5639(95.4 \%) 5326$ & ibid. \\
\hline$-11-$ & & Deb-13045 & 6462 & 48 & $5492(95.4 \%) 5324$ & Lászlo Domboróczki 2012.108 \\
\hline \multirow[t]{2}{*}{$-11-$} & & VERA-4243 & 6245 & 30 & $5309(95.4 \%) 5076$ & ibid. \\
\hline & & & \multicolumn{2}{|c|}{ BULGARIA } & & \\
\hline Azmak (1) & $\begin{array}{l}42^{\circ} 27^{\prime} 6.06^{\prime \prime} \mathrm{N} \\
25^{\circ} 43^{\prime} 0.61^{\prime \prime} \mathrm{E}\end{array}$ & Bln-293 & 7303 & 150 & $6452(95.4 \%) 5901$ & $\begin{array}{l}\text { Görsdorf, Bojadžiev } 1996 . \\
\text { 133-136 }\end{array}$ \\
\hline Azmak & & Bln-291 & 7158 & 150 & $6361(95.4 \%) 5739$ & ibid. \\
\hline Azmak & & $B \ln -292$ & 6878 & 100 & $5982(95.4 \%) 5625$ & ibid. \\
\hline Azmak & & Bln-294 & 6768 & 100 & $5877(95.4 \%) 5494$ & ibid. \\
\hline Azmak & & Bln-296 & 6779 & 100 & $5886(95.4 \%) 5516$ & ibid. \\
\hline Azmak & & Bln-295 & 6720 & 100 & $5808(95.4 \%) 5479$ & ibid. \\
\hline Azmak & & $\mathrm{Bln}-2 \mathrm{O} 3$ & 6870 & 100 & $5983(95.4 \%) 5621$ & ibid. \\
\hline Azmak & & Bln-299 & 6812 & 100 & $5968(95.4 \%) 5542$ & ibid. \\
\hline Azmak & & $B \ln -267$ & 6758 & 100 & $5846(95.4 \%) 5487$ & ibid. \\
\hline Azmak & & Bln-224 & 6650 & 150 & $5872(95.4 \%) 5317$ & ibid. \\
\hline Azmak & & Bln-297 & 6675 & 100 & $5776(95.4 \%) 5390$ & ibid. \\
\hline Azmak & & $B \ln -298$ & 6540 & 100 & $5643(95.4 \%) 5317$ & ibid. \\
\hline Azmak & & Bln-300 & 6426 & 150 & $5641(95.4 \%) 5043$ & ibid. \\
\hline Azmak & & Bln-301 & 6483 & $100(1,3)$ & $5625(95.4 \%) 5231$ & ibid. \\
\hline Azmak & & $B \ln -430$ & 6279 & 120 & 5479 (95.4\%) 4953 & ibid. \\
\hline Azmak & & Bln-140A & 6476 & 100 & $5622(95.4 \%) 5230$ & ibid. \\
\hline $\begin{array}{l}\text { Chavdar (Čavdar) } \\
\text { (2) }\end{array}$ & $\begin{array}{l}42^{\circ} 41^{\prime} 38.57^{\prime \prime} \mathrm{N} \\
24^{\circ} 3^{\prime} 1.33^{\prime \prime} \mathrm{E}\end{array}$ & Bln-1583 & 6994 & 55 & $5988(95.4 \%) 5753$ & $\begin{array}{l}\text { Görsdorf, Bojadžiev } 1996 . \\
\text { 124-126 }\end{array}$ \\
\hline Chavdar (Čavdar) & & $B \ln -1580$ & 7003 & 45 & $5990(95.4 \%) 5775$ & ibid. \\
\hline Chavdar (Čavdar) & & $B \ln -2108$ & 7195 & 65 & $6221(95.4 \%) 5929$ & ibid. \\
\hline Chavdar (Čavdar) & & $B \ln -1663$ & 7070 & 50 & $6034(95.4 \%) 5843$ & ibid. \\
\hline Chavdar (Čavdar) & & Bln-1582 & 7020 & 45 & $6001(95.4 \%) 5796$ & ibid. \\
\hline Chavdar (Čavdar) & & Bln-1581 & 7000 & 60 & $5995(95.4 \%) 5749$ & ibid. \\
\hline Chavdar (Čavdar) & & $B \ln -1578$ & 6994 & 55 & $5988(95.4 \%) 5753$ & ibid. \\
\hline Chavdar (Čavdar) & & $B \ln -2662$ & 6400 & 100 & $5606(95.4 \%) 5080$ & ibid. \\
\hline Chavdar (Čavdar) & & $B \ln -2107$ & 6550 & 50 & $5619(95.4 \%) 5385$ & ibid. \\
\hline Chavdar (Čavdar) & & $B \ln -4261$ & 7120 & 80 & $6211(95.4 \%) 5837$ & ibid. \\
\hline Chavdar (Čavdar) & & Bln-4106 & 6840 & 50 & $5837(95.4 \%) 5639$ & ibid. \\
\hline Chavdar (Čavdar) & & Bln-1241 & 6852 & 100 & $5981(95.4 \%) 5570$ & ibid. \\
\hline Chavdar (Čavdar) & & Bln-1241 A & 6830 & 100 & $5976(95.4 \%) 5560$ & ibid. \\
\hline Chavdar (Čavdar) & & $B \ln -1162$ & 6400 & 100 & $5606(95.4 \%) 5080$ & ibid. \\
\hline Chavdar (Čavdar) & & $B \ln -1162 \mathrm{~A}$ & 6985 & 100 & $6047(95.4 \%) 5676$ & ibid. \\
\hline Chavdar (Čavdar) & & Bln-1251 & 6997 & 100 & $6059(95.4 \%) 5708$ & ibid. \\
\hline Chavdar (Čavdar) & & Bln-116o & 6680 & 100 & $5782(95.4 \%) 5469$ & ibid. \\
\hline Chavdar (Čavdar) & & Bln-116o A & 7040 & 100 & $6085(95.4 \%) 5720$ & ibid. \\
\hline Chavdar (Čavdar) & & Bln-908 & 6990 & 150 & $6207(95.4 \%) 5626$ & ibid. \\
\hline Chavdar (Čavdar) & & Bln-911 & 6870 & 120 & $5998(95.4 \%) 5564$ & ibid. \\
\hline Chavdar (Čavdar) & & Bln-909 & 6815 & 100 & $5970(95.4 \%) 5546$ & ibid. \\
\hline Chavdar (Čavdar) & & Bln-910 & 6665 & 100 & $5753(95.4 \%) 5385$ & ibid. \\
\hline Chavdar (Čavdar) & & Bln-910 A & 6555 & 100 & $5657(95.4 \%) 5323$ & ibid. \\
\hline Chavdar (Čavdar) & & Bln-907 & 6320 & 100 & $5481(95.4 \%) 5046$ & ibid. \\
\hline Chavdar (Čavdar) & & $B \ln -1030$ & 6760 & 100 & $5868(95.4 \%) 5488$ & ibid. \\
\hline Chavdar (Čavdar) & & Bln-906 & 6720 & 100 & $5808(95.4 \%) 5479$ & ibid. \\
\hline $\begin{array}{l}\text { Dobrinishte } \\
\text { (Dobrinište) (3) }\end{array}$ & $\begin{array}{l}41^{\circ} 51^{\prime} 6.48^{\prime \prime} \mathrm{N} \\
23^{\circ} 35^{\prime} 4.94^{\prime \prime} \mathrm{E}\end{array}$ & Bln-3785 & 6650 & 60 & $5661(95.4 \%) 5484$ & Görsdorf, Bojadžiev 1996.127 \\
\hline
\end{tabular}




\begin{tabular}{|c|c|c|c|c|c|c|}
\hline $\begin{array}{l}\text { Site (No. on } \\
\text { the Fig. 1) }\end{array}$ & Coordinates & Lab. No & $\begin{array}{c}\text { Uncal. } \\
\text { BP }\end{array}$ & $\begin{array}{l}\text { St. } \\
\text { error }\end{array}$ & Cal BC & Reference \\
\hline $\begin{array}{l}\text { Dobrinishte } \\
\text { (Dobrinište) }\end{array}$ & & Bln-3786 & 6610 & 50 & $5623(95.4 \%) 5483$ & Görsdorf, Bojadžiev 1996.127 \\
\hline $\begin{array}{l}\text { Džuljunica- } \\
\text { Smărdeš (15) }\end{array}$ & $\begin{array}{l}43^{\circ} 7^{\prime} 17.50^{\prime \prime} \mathrm{N} \\
25^{\circ} 54^{\prime} 17.44^{\prime \prime} \mathrm{E}\end{array}$ & OxA-25045 & 6686 & 39 & 5669 (95.4\%) 5531 & Krauß et al. 2014.51-77 \\
\hline$-\overline{-11-}$ & & OxA-25047 & 7140 & 40 & $6075(95.4 \%) 5920$ & Krauß et al. 2014.51-77 \\
\hline$-11-$ & & OxA-25046 & 6950 & 40 & 5971 (95.4\% 5736 & Krauß et al. 2014.51-77 \\
\hline$-11-$ & & OxA-24981 & 7185 & 40 & $6205(95.4 \%) 5987$ & Krauß et al. 2014.51-77 \\
\hline$-11-$ & & OxA-25043 & 7055 & 40 & $6013(95.4 \%) 5846$ & Krauß et al. 2014.51-77 \\
\hline$-11-$ & & OxA-24977 & 7136 & 40 & $6073(95.4 \%) 5919$ & Krauß et al. 2014.51-77 \\
\hline$-11-$ & & OxA-24978 & 7054 & 39 & $6012(95.4 \%) 5847$ & Krauß et al. 2014.51-77 \\
\hline$-11-$ & & OxA-24939 & 717 & 36 & $6094(95.4 \%) 5985$ & Krauß et al. 2014.51-77 \\
\hline$-11-$ & & OxA-24935 & 7026 & 35 & $5995(95.4 \%) 5840$ & Krauß et al. 2014.51-77 \\
\hline$-11-$ & & OxA-24931 & 7066 & 38 & $6020(95.4 \%) 5878$ & Krauß et al. 2014.51-77 \\
\hline$-11-$ & & OxA-24932 & 7053 & 35 & $6010(95.4 \%) 5849$ & Krauß et al. 2014.51-77 \\
\hline$-11-$ & & OxA-25040 & 7049 & 39 & $6008(95.4 \%) 5846$ & Krauß et al. 2014.51-77 \\
\hline$-11-$ & & OxA-24938 & 7134 & 35 & $6067(95.4 \%) 5923$ & Krauß et al. 2014.51-77 \\
\hline$-11-$ & & OxA-25044 & 7095 & 40 & $6048(95.4 \%) 5896$ & Krauß et al. 2014.51-77 \\
\hline$-11-$ & & OxA-24979 & 7145 & 38 & $6075(95.4 \%) 5925$ & Krauß et al. 2014.51-77 \\
\hline$-11-$ & & OxA-25033 & 7084 & 36 & $6026(95.4 \%) 5891$ & Krauß et al. 2014.51-77 \\
\hline$-11-$ & & OxA-24980 & 7011 & 38 & $5990(95.4 \%) 5802$ & Krauß et al. 2014.51-77 \\
\hline$-11-$ & & OxA-24937 & 7588 & 37 & $6491(95.4 \%) 6396$ & Krauß et al. 2014.51-77 \\
\hline$-11-$ & & OxA-25042 & 7095 & 40 & $6048(95.4 \%) 5896$ & Krauß et al. 2014.51-77 \\
\hline$-11-$ & & OxA-24934 & 7195 & 37 & $6205(95.4 \%) 5995$ & Krauß et al. 2014.51-77 \\
\hline$-11-$ & & OxA-24936 & 7083 & 36 & $6025(95.4 \%) 5892$ & Krauß et al. 2014.51-77 \\
\hline $\begin{array}{l}\text { Eleshnitsa } \\
\text { (Elešnitsa, } \\
\text { Elešnica) (4) } \\
\end{array}$ & $\begin{array}{l}41^{\circ} 54^{\prime} 33.91^{\prime \prime} \mathrm{N} \\
23^{\circ} 39^{\prime} 54.10^{\prime \prime} \mathrm{E}\end{array}$ & $B \ln -3238$ & 7010 & 60 & $6002(95.4 \%) 5758$ & Görsdorf, Bojadžiev 1996.126-127 \\
\hline Eleshnitsa & & $B \ln -3241$ & 6960 & 60 & $5982(95.4 \%) 5730$ & Görsdorf, Bojadžiev 1996.126-127 \\
\hline Eleshnitsa & & $B \ln -3242$ & 6940 & 50 & $5974(95.4 \%) 5726$ & Görsdorf, Bojadžiev 1996.126-127 \\
\hline Eleshnitsa & & $B \ln -3239$ & 6920 & 60 & $5978(95.4 \%) 5677$ & Görsdorf, Bojadžiev 1996.126-127 \\
\hline Eleshnitsa & & Bln-3940 & 6850 & 50 & $5841(95.4 \%) 5643$ & Görsdorf, Bojadžiev 1996.126-127 \\
\hline Eleshnitsa & & $B \ln -3245$ & 6730 & 90 & $5786(95.4 \%) 5485$ & Görsdorf, Bojadžiev 1996.126-127 \\
\hline Eleshnitsa & & $B \ln -3237$ & 6790 & 50 & $5762(95.4 \%) 5620$ & Görsdorf, Bojadžiev 1996.126-127 \\
\hline Eleshnitsa & & Bln-3244 & 6720 & 70 & $5736(95.4 \%) 5514$ & Görsdorf, Bojadžiev 1996.126-127 \\
\hline Galabnik (5) & $\begin{array}{c}42^{\circ} 26^{\prime} 49.35^{\prime \prime} \mathrm{N} \\
23^{\circ} 5^{\prime} 54.29^{\prime \prime} \mathrm{E}\end{array}$ & Bln-3580 & 7120 & 70 & $6205(95.4 \%) 5842$ & Görsdorf, Bojadžiev 1996.122-123 \\
\hline Galabnik & & $B \ln -3579$ & 7030 & 70 & $6022(95.4 \%) 5752$ & Görsdorf, Bojadžiev 1996.122-123 \\
\hline Galabnik & & $\mathrm{Bln}-3579 \mathrm{H}$ & 7220 & 80 & $6245(95.4 \%) 5920$ & Görsdorf, Bojadžiev 1996.122-123 \\
\hline Galabnik & & $B \ln -3582$ & 6950 & 70 & $5986(95.4 \%) 5719$ & Görsdorf, Bojadžiev 1996.122-123 \\
\hline Galabnik & & $B \ln -3581$ & 6790 & 80 & $5870(95.4 \%) 5551$ & Görsdorf, Bojadžiev 1996.122-123 \\
\hline Galabnik & & GrN-19786 & 7070 & 180 & $6352(95.4 \%) 5632$ & Görsdorf, Bojadžiev 1996.122-123 \\
\hline Galabnik & & GrN-19785 & 7020 & 60 & $6010(95.4 \%) 5763$ & Görsdorf, Bojadžiev 1996.122-123 \\
\hline Galabnik & & GrN-19784 & 7070 & 60 & $6060(95.4 \%) 5812$ & Görsdorf, Bojadžiev 1996.122-123 \\
\hline Galabnik & & Bln-4095 & 7020 & 150 & $6211(95.4 \%) 5643$ & Görsdorf, Bojadžiev 1996.122-123 \\
\hline Galabnik & & Bln-4096 & 7140 & 80 & $6213(95.4 \%) 5849$ & Görsdorf, Bojadžiev 1996.122-123 \\
\hline Galabnik & & Bln-4094 & 6760 & 80 & $5834(95.4 \%) 5527$ & Görsdorf, Bojadžiev 1996.122-123 \\
\hline Galabnik & & Bln-4093 & 7100 & 80 & $6203(95.4 \%) 5783$ & Görsdorf, Bojadžiev 1996.122-123 \\
\hline Galabnik & & GrN-19783 & 6970 & 50 & $5981(95.4 \%) 5740$ & Görsdorf, Bojadžiev 1996.122-123 \\
\hline Galabnik & & Bln-4091 & 6760 & 60 & $5751(95.4 \%) 5558$ & Görsdorf, Bojadžiev 1996.122-123 \\
\hline Galabnik & & Bln-4092 & 6710 & 60 & $5723(95.4 \%) 5529$ & Görsdorf, Bojadžiev 1996.122-123 \\
\hline Galabnik & & $B \ln -3576$ & 6670 & 70 & $5706(95.4 \%) 5486$ & Görsdorf, Bojadžiev 1996.122-123 \\
\hline Karanovo (6) & $\begin{array}{c}42^{\circ} 30^{\prime} 45.67 " \mathrm{~N} \\
25^{\circ} 54^{\prime} 55.43^{\prime \prime} \mathrm{E}\end{array}$ & Bln-4339 & 7090 & 90 & $6203(95.4 \%) 5750$ & $\begin{array}{l}\text { Görsdorf, Weninger 1993; } \\
\text { Gorsdorf, Bojadziev 1996.133-136; } \\
\text { Kohl, Quitta 1966; } \\
\text { Quitta, Kohl 1969.37 }\end{array}$ \\
\hline
\end{tabular}


Tamara Blagojević, Marko Porčić, Kristina Penezić and Sofija Stefanović

\begin{tabular}{|c|c|c|c|c|c|c|}
\hline $\begin{array}{l}\text { Site (No. on } \\
\text { the Fig. 1) }\end{array}$ & Coordinates & Lab. No & $\left|\begin{array}{c}\text { Uncal. } \\
\text { BP }\end{array}\right|$ & $\begin{array}{c}\text { St. } \\
\text { error }\end{array}$ & Cal BC & Reference \\
\hline Karanovo & & $B \ln -4336$ & 7110 & 50 & $6067(95.4 \%) 5892$ & ibid. \\
\hline Karanovo & & $B \ln -4338$ & 6955 & 45 & $5975(95.4 \%) 5736$ & ibid. \\
\hline Karanovo & & $B \ln -4337$ & 6810 & 65 & $5842(95.4 \%) 5618$ & ibid. \\
\hline Karanovo & & Bln-4335 & 6710 & 55 & $5719(95.4 \%) 5535$ & ibid. \\
\hline Karanovo & & Bln-3942 & 6820 & 50 & $5803(95.4 \%) 5629$ & ibid. \\
\hline Karanovo & & Bln-4177 & 7110 & 50 & $6067(95.4 \%) 5892$ & ibid. \\
\hline Karanovo & & Bln-4179 & 7130 & 70 & $6206(95.4 \%) 5846$ & ibid. \\
\hline Karanovo & & $B \ln -4178$ & 6730 & 80 & $5756(95.4 \%) 5490$ & ibid. \\
\hline Karanovo & & Bln-3943 & 6760 & 50 & $5736(95.4 \%) 5569$ & ibid. \\
\hline Karanovo & & Bln-3941 & 6750 & 50 & $5732(95.4 \%) 5565$ & ibid. \\
\hline Karanovo & & Bln-3944 & 6785 & 60 & $5794(95.4 \%) 5566$ & ibid. \\
\hline Karanovo & & $B \ln -3716$ & 6910 & 60 & $5972(95.4 \%) 5674$ & $\begin{array}{l}\text { Görsdorf, Weninger 1993; } \\
\text { Gorsdorf, Bojadziev 1996.133-136; } \\
\text { Kohl, Quitta 1966; } \\
\text { Quitta, Kohl 1969.37 }\end{array}$ \\
\hline Karanovo & & $\mathrm{Bln}-3716 \mathrm{H}$ & 6850 & 60 & $5873(95.4 \%) 5635$ & ibid. \\
\hline Karanovo & & $B \ln -3586$ & 6780 & 60 & $5788(95.4 \%) 5565$ & ibid. \\
\hline Karanovo & & Bln-152 & 6807 & 100 & $5966(95.4 \%) 5536$ & ibid. \\
\hline Karanovo & & Bln-201 & 6540 & 100 & $5643(95.4 \%) 5317$ & ibid. \\
\hline Karanovo & & Bln-234 & 6490 & 150 & $5716(95.4 \%) 5079$ & ibid. \\
\hline Karanovo & & Bln-3904 & 6375 & 70 & $5476(95.4 \%) 5224$ & ibid. \\
\hline Karanovo & & $B \ln -3458$ & 6440 & 60 & $5509(95.4 \%) 5309$ & ibid. \\
\hline Karanovo & & $B \ln -3459$ & 6420 & 60 & $5491(95.4 \%) 5236$ & ibid. \\
\hline Karanovo & & Bln-3460 & 6440 & 60 & $5509(95.4 \%) 5309$ & ibid. \\
\hline Karanovo & & $B \ln -3461$ & 6480 & 60 & $5545(95.4 \%) 5321$ & ibid. \\
\hline Karanovo & & $B \ln -3464$ & 6500 & 50 & $5602(95.4 \%) 5358$ & ibid. \\
\hline Karanovo & & $B \ln -3463$ & 6350 & 60 & $5469(95.4 \%) 5221$ & ibid. \\
\hline Karanovo & & $B \ln -3465$ & 6410 & 60 & $5486(95.4 \%) 5232$ & ibid. \\
\hline Karanovo & & $B \ln -3587$ & 6380 & 60 & $5476(95.4 \%) 5227$ & ibid. \\
\hline Karanovo & & $B \ln -3717$ & 6450 & 60 & $5513(95.4 \%) 5315$ & ibid. \\
\hline Karanovo & & $\mathrm{Bln}-3717 \mathrm{H}$ & 6510 & 60 & $5613(95.4 \%) 5345$ & ibid. \\
\hline Karanovo & & $B \ln -158$ & 6395 & 100 & $5558(95.4 \%) 5079$ & ibid. \\
\hline Kazanlak (7) & \begin{tabular}{|l|}
$42^{\circ} 38^{\prime} 14.05^{\prime \prime} \mathrm{N}$ \\
$25^{\circ} 23^{\prime} 39.76^{\prime \prime} \mathrm{E}$
\end{tabular} & Bln-730 & 6335 & 160 & $5616(95.4 \%) 4935$ & $\begin{array}{l}\text { Georgiev 1974; Nikolov, } \\
\text { Karastoyanova } 2003\end{array}$ \\
\hline Kazanlak & & Bln-729 & 6330 & 100 & $5482(95.4 \%) 5053$ & ibid. \\
\hline $\begin{array}{l}\text { Kovachevo } \\
\text { (Kovačevo) (8) }\end{array}$ & $\begin{array}{c}41^{\circ} 30^{\prime} 20.16^{\prime \prime} \mathrm{N} \\
23^{\circ} 28^{\prime} 11.55^{\prime \prime} \mathrm{E}\end{array}$ & Ly-1437 (OxA) & 7180 & 45 & $6207(95.4 \%) 5983$ & $\begin{array}{l}\text { Grebska-Kulova 2008; Lichardus- } \\
\text { Itten et al. 2000; 2002; 2006; Ko- } \\
\text { vacheva 1995; Pemitcheva } 1990\end{array}$ \\
\hline Kovachevo & & Ly-1654 (OxA) & 7090 & 70 & 6081 (95.4\%) 5796 & ibid. \\
\hline Kovachevo & & Ly-1439 (OxA) & 6975 & 50 & $5982(95.4 \%) 5743$ & ibid. \\
\hline Kovachevo & & Ly-1438 (OxA) & 6990 & 45 & $5984(95.4 \%) 5764$ & ibid. \\
\hline Kovachevo & & Ly-1620 (OxA) & 6980 & 65 & $5988(95.4 \%) 5737$ & ibid. \\
\hline Kovachevo & & Ly-6553 & 6760 & 160 & $5992(95.4 \%) 5385$ & ibid. \\
\hline Kovachevo & & Ly-6554 & 6830 & 85 & $5963(95.4 \%) 5566$ & ibid. \\
\hline $\begin{array}{l}\text { Kremenik (Sapareva } \\
\text { Bania) (Sapareva } \\
\text { Banja) (9) } \\
\end{array}$ & $\begin{array}{l}42^{\circ} 22^{\prime} \mathrm{O} .09^{\prime \prime} \mathrm{N} \\
23^{\circ} 3^{\prime} 53.50^{\prime \prime} \mathrm{E}\end{array}$ & Bln-2554 & 6620 & 100 & $5720(95.4 \%) 5377$ & Görsdorf, Bojadžiev 1996.127-128 \\
\hline Kremenik & & $B \ln -2552$ & 6460 & 60 & $5524(95.4 \%) 5317$ & Görsdorf, Bojadžiev 1996.127-128 \\
\hline Kremenik & & Bln-2554A & 6840 & 60 & $5868(95.4 \%) 5629$ & Görsdorf, Bojadžiev 1996.127-128 \\
\hline Kremenik & & Bln-2553 & 6660 & 60 & $5671(95.4 \%) 5483$ & Görsdorf, Bojadžiev 1996.127-128 \\
\hline Kremenik & & Bln-2105 & 6530 & 50 & $5612(95.4 \%) 5376$ & Görsdorf, Bojadžiev 1996.127-128 \\
\hline Kremenik & & $B \ln -2556$ & 6480 & 60 & $5545(95.4 \%) 5321$ & Görsdorf, Bojadžiev 1996.127-128 \\
\hline Kremenik & & $B \ln -2106$ & 6475 & 40 & $5516(95.4 \%) 5357$ & Görsdorf, Bojadžiev 1996.127-128 \\
\hline Kremenik & & $B \ln -2550$ & 6550 & 60 & $5621(95.4 \%) 5379$ & Görsdorf, Bojadžiev 1996.127-128 \\
\hline Kremenik & & $B \ln -2551$ & 6450 & 100 & $5613(95.4 \%) 5224$ & Görsdorf, Bojadžiev 1996.127-128 \\
\hline
\end{tabular}




\begin{tabular}{|c|c|c|c|c|c|c|}
\hline $\begin{array}{l}\text { Site (No. on } \\
\text { the Fig. 1) }\end{array}$ & Coordinates & Lab. No & $\begin{array}{c}\text { Uncal. } \\
\text { BP }\end{array}$ & $\left|\begin{array}{c}\text { St. } \\
\text { error }\end{array}\right|$ & Cal BC & Reference \\
\hline Kremenik & & $B \ln -2549$ & 6350 & 60 & $5469(95.4 \%) 5221$ & Görsdorf, Bojadžiev 1996.127-128 \\
\hline Ohoden (12) & \begin{tabular}{|l|}
$43^{\circ} 23^{\prime} 7.84^{\prime \prime} \mathrm{N}$ \\
$23^{\circ} 42^{\prime} 49.36^{\prime \prime} \mathrm{E}$
\end{tabular} & $K N-5655$ & 6830 & 45 & $5803(95.4 \%) 5636$ & Ganetovski, G. 2007 \\
\hline $\begin{array}{l}\text { Ovčarovo-gorata } \\
\text { (13) }\end{array}$ & $\begin{array}{l}43^{\circ} 6^{\prime} 43.05^{\prime \prime} \mathrm{N} \\
26^{\circ} 39^{\prime} 13.20^{\prime \prime} \mathrm{E}\end{array}$ & Bln-1544 & 6688 & 60 & $5715(95.4 \%) 5511$ & Görsdorf, Bojadžiev 1996.128-129 \\
\hline Ovčarovo-gorata & & $B \ln -1620$ & 6463 & 50 & $5509(95.4 \%) 5324$ & Görsdorf, Bojadžiev 1996.128-129 \\
\hline Ovčarovo-gorata & & $\mathrm{B} \ln -2032$ & 6555 & 70 & $5625(95.4 \%) 5376$ & Görsdorf, Bojadžiev 1996.128-129 \\
\hline Ovčarovo-gorata & & Poz-16984 & 6890 & 40 & $5882(95.4 \%) 5707$ & Krauß 2014.174-200 \\
\hline Ovčarovo-gorata & & Poz-16985 & 6890 & 40 & $5882(95.4 \%) 5707$ & Krauß 2014.174-200 \\
\hline Ovčarovo-gorata & & Poz-16986 & 6500 & 40 & $5535(95.4 \%) 5371$ & Krauß 2014.174-200 \\
\hline Ovčarovo-gorata & & Poz-18480 & 6900 & 40 & $5881(95.4 \%) 5716$ & Krauß 2014.174-200 \\
\hline Ovčarovo-gorata & & Poz-18483 & 6750 & 40 & $5726(95.4 \%) 5575$ & Krauß 2014.174-200 \\
\hline Ovčarovo-gorata & & Poz-18484 & 6640 & 40 & $5632(95.4 \%) 5494$ & Krauß 2014.174-200 \\
\hline Ovčarovo-gorata & & Poz-18486 & 6800 & 40 & $5741(95.4 \%) 5631$ & Krauß 2014.174-200 \\
\hline Ovčarovo-gorata & & Poz-18487 & 6660 & 40 & $5646(95.4 \%) 5512$ & Krauß 2014.174-200 \\
\hline Ovčarovo-gorata & & Poz-18489 & 6750 & 40 & $5726(95.4 \%) 5575$ & Krauß 2014.174-200 \\
\hline Ovčarovo-gorata & & Poz-18490 & 6780 & 40 & $5730(95.4 \%) 5628$ & Krauß 2014.174-200 \\
\hline Ovčarovo-gorata & & Poz-18491 & 6810 & 40 & $5754(95.4 \%) 5631$ & Krauß 2014.174-200 \\
\hline Ovčarovo-gorata & & Poz-18493 & 6670 & 40 & $5659(95.4 \%) 5522$ & Krauß 2014.174-200 \\
\hline Ovčarovo-gorata & & Poz-18494 & 6690 & 40 & $5674(95.4 \%) 5529$ & Krauß 2014.174-200 \\
\hline $\begin{array}{l}\text { Ovcharovo-platoto } 2 \\
\text { (Ovčarovo-platoto 2) } \\
(16)\end{array}$ & $\begin{array}{l}43^{\circ} 11 ' 39^{\prime \prime} \mathrm{N} \\
26^{\circ} 38^{\prime} 12 " \mathrm{E}\end{array}$ & Bln-1356 & 6480 & 60 & $5545(95.4 \%) 5321$ & Görsdorf, Bojadžiev 1996.129 \\
\hline $\begin{array}{l}\text { Polyanitsa-platoto } \\
\text { (Poljanica-platoto) } \\
\text { (14) }\end{array}$ & $\begin{array}{l}43^{\circ} 14^{\prime} 30.22 " \mathrm{~N} \\
26^{\circ} 35^{\prime} 29.18^{\prime \prime} \mathrm{E}\end{array}$ & Bln-1571 & 7535 & 80 & $6563(95.4 \%) 6230$ & Görsdorf, Bojadžiev 1996.121-122 \\
\hline Polyanitsa-platoto & & Bln-1512 & 7140 & 80 & $6213(95.4 \%) 5849$ & Görsdorf, Bojadžiev 1996.121-122 \\
\hline Polyanitsa-platoto & & $B \ln -1613$ & 7380 & 60 & $6392(95.4 \%) 6094$ & Görsdorf, Bojadžiev 1996.121-122 \\
\hline Polyanitsa-platoto & & $B \ln -1613 \mathrm{~A}$ & 7275 & 60 & $6242(95.4 \%) 6020$ & Görsdorf, Bojadžiev 1996.121-122 \\
\hline Slatina (10) & \begin{tabular}{|}
$42^{\circ} 41^{\prime} 18.06^{\prime \prime} \mathrm{N}$ \\
$23^{\circ} 21^{\prime} 56.18^{\prime \prime} \mathrm{E}$
\end{tabular} & Bln-3434 & 6890 & 60 & $5963(95.4 \%) 5661$ & Görsdorf, Bojadžiev 1996 \\
\hline Slatina & & $B \ln -3435$ & 6860 & 50 & $5869(95.4 \%) 5644$ & Görsdorf, Bojadžiev 1996 \\
\hline Slatina & & $B \ln -3436$ & 6840 & 60 & $5868(95.4 \%) 5629$ & Görsdorf, Bojadžiev 1996 \\
\hline Slatina & & $B \ln -3437$ & 6810 & 50 & $5789(95.4 \%) 5626$ & Görsdorf, Bojadžiev 1996 \\
\hline Slatina & & $B \ln -3438$ & 6960 & 60 & $5982(95.4 \%) 5730$ & Görsdorf, Bojadžiev 1996 \\
\hline Slatina & & Bln-3439 & 6940 & 60 & $5981(95.4 \%) 5718$ & Görsdorf, Bojadžiev 1996 \\
\hline Slatina & & Bln-3440 & 6840 & 60 & $5868(95.4 \%) 5629$ & Görsdorf, Bojadžiev 1996 \\
\hline Slatina & & $B \ln -3441$ & 6960 & 60 & $5982(95.4 \%) 5730$ & Görsdorf, Bojadžiev 1996 \\
\hline Slatina & & $B \ln -3442$ & 6780 & 60 & $5788(95.4 \%) 5565$ & Görsdorf, Bojadžiev 1996 \\
\hline Slatina & & $B \ln -3443$ & 6840 & 60 & $5868(95.4 \%) 5629$ & Görsdorf, Bojadžiev 1996 \\
\hline Slatina & & Bln-3504 & 6970 & 60 & $5983(95.4 \%) 5736$ & Görsdorf, Bojadžiev 1996 \\
\hline Slatina & & Bln-3555 & 6930 & 60 & $5980(95.4 \%) 5712$ & Görsdorf, Bojadžiev 1996 \\
\hline $\begin{array}{l}\text { Stara Zagora- } \\
\text { Okrazhna bolnitsa } \\
\text { (Okražna Bolnica) } \\
\text { (11) }\end{array}$ & $\begin{array}{c}42^{\circ} 25^{\prime} 45.00^{\prime \prime} \mathrm{N} \\
25^{\circ} 36^{\prime} 17.97^{\prime \prime} \mathrm{E}\end{array}$ & Bln-1587 & 7139 & 65 & $6207(95.4 \%) 5886$ & Görsdorf, Bojadžiev 1996 \\
\hline$-11-$ & & $B \ln -1586$ & 6814 & 65 & $5843(95.4 \%) 5619$ & Görsdorf, Bojadžiev 1996 \\
\hline$-11-$ & & Bln-1589 & 6918 & 45 & $5902(95.4 \%) 5717$ & Görsdorf, Bojadžiev 1996 \\
\hline$-11-$ & & $B \ln -1252$ & 6844 & 100 & $5979(95.4 \%) 5565$ & Görsdorf, Bojadžiev 1996 \\
\hline$-11-$ & & Bln-1250 & 6820 & 100 & $5972(95.4 \%) 5556$ & Görsdorf, Bojadžiev 1996 \\
\hline$-11-$ & & $B \ln -1163$ & 6688 & 150 & $5896(95.4 \%) 5345$ & Görsdorf, Bojadžiev 1996 \\
\hline$-11-$ & & $B \ln -1588$ & 6750 & 60 & $5743(95.4 \%) 5555$ & Görsdorf, Bojadžiev 1996 \\
\hline$-11-$ & & $B \ln -1164$ & 6723 & 100 & $5809(95.4 \%) 5480$ & Görsdorf, Bojadžiev 1996 \\
\hline$-11-$ & & Bln-1164 & 6744 & 100 & $5837(95.4 \%) 5487$ & Görsdorf, Bojadžiev 1996 \\
\hline
\end{tabular}

